\title{
Boots on the Ground: A Historical and Contemporary Analysis of Force Levels for Counterinsurgency Operations
}

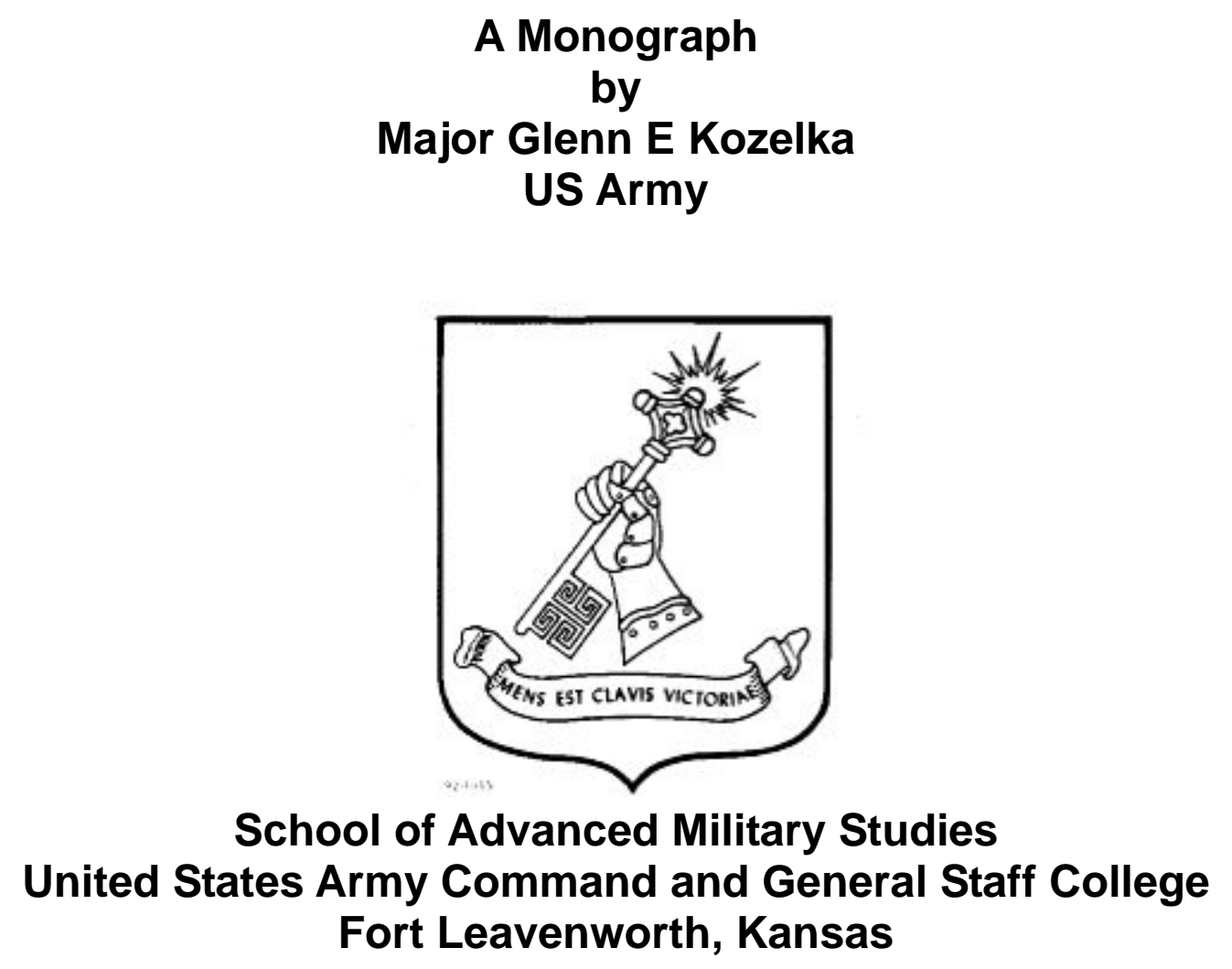

AY 2008 


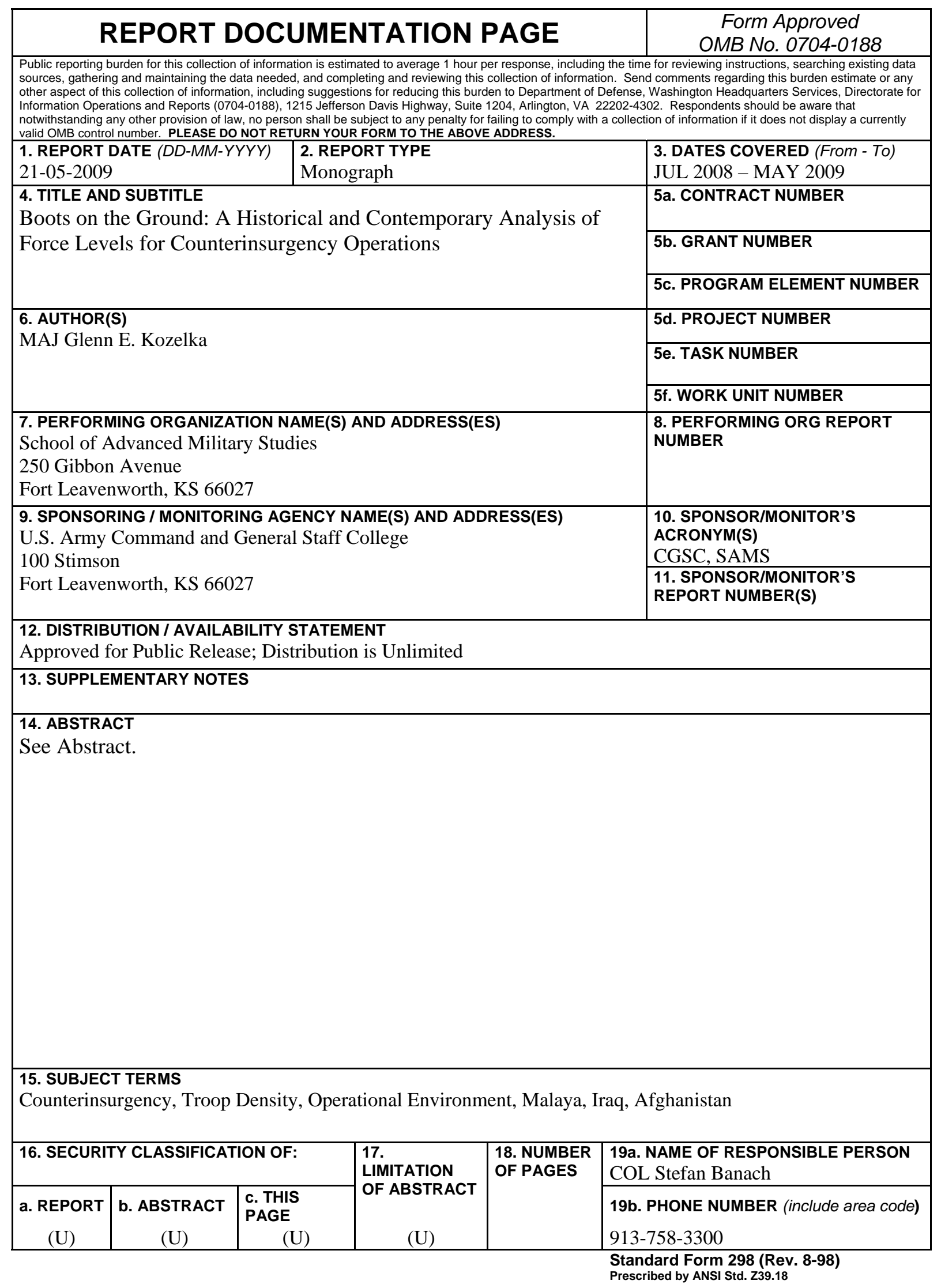




\section{SCHOOL OF ADVANCED MILITARY STUDIES MONOGRAPH APPROVAL}

MAJ Glenn E. Kozelka

Title of Monograph: Boots on the Ground: A Historical and Contemporary Analysis of Force Levels for Counterinsurgency Operations

This monograph was defended by the degree candidate on 7-April-2009 approved by the monograph director and reader named below.

Approved by:

Dan C. Fullerton, Ph.D.

Monograph Director

Jerome K. Hawkins, COL, FA

Monograph Reader

Director,

Stefan J. Banach, COL, IN

School of Advanced

Military Studies

Robert F. Baumann, Ph.D.

Director,

Graduate Degree

Programs 


\begin{abstract}
Boots on the Ground: A Historical and Contemporary Analysis of Force Levels for Counterinsurgency Operations, by Major Glenn E. Kozelka, US Army, 81 pages.

In the wake of military operations in Iraq and Afghanistan, one of the most intensely debated issues concerning the conduct of the war has been the level of troops committed to the effort. Military observers, policy makers, military officers, and media pundits have discussed this issue obsessively. This monograph uses this debate and current operations as the impetus to further examine the force levels required for counterinsurgency (COIN) operations.
\end{abstract}

Although the US military has a long history of executing "small wars," the intellectual effort to capture, refine, and codify lessons and guidance on the subject of COIN has been insufficient until the publishing of FM 3-24 in 2006. Even this manual, however, lacks the level of analysis planners require to accurately determine the force levels for a given environment. Therefore, the purpose of this work is to analyze the relevant force density theories against case studies to provide a comprehensive analysis of the critical qualitative and quantitative factors in determining a valid force size for conducting COIN operations in a given environment.

To determine a historical gauge for planning force levels in a COIN environment, this study provides a quantitative and qualitative analysis of two successful COIN case studies, the Britishled Malaya Emergency and the US-led Operation in Iraq. Quantitative analysis of the case studies is used to compare the security force size employed to the population size. The qualitative analysis of the case studies is used to identify and assess the implications of specific operational environment factors on the force density used. Through applying a holistic approach of both quantitative and qualitative analysis, planners can more accurately determine the force density to meet the needs of a specific situation.

Although each situation is unique and a fixed ratio will not guarantee success, there is a strong correlative relationship between force levels and success. This is because in COIN, numbers do matter. The COIN force must have adequate strength to establish and maintain widespread security to protect the population against insurgent violence and intimidation. The case studies show that the closer force levels approach the ratio of 20 security forces per 1000 population, the greater the possibility the COIN force will reach the tipping point to success. When the nature of the war being fought is COIN, the strategy and force size must be nested with providing security for the people.

In addition providing a doctrinal review and a historical and contemporary analysis of force levels, this work includes five important force level implications that emerged during the study. They include, 1) numbers do matter; 2) the size of the US Army will limit its flexibility in future operations; 3) the need to incorporate host-nation forces early in operations; 4) strategies will change during operations; and 5) the military alone is insufficient to succeed in a COIN environment. 


\section{TABLE OF CONTENTS}

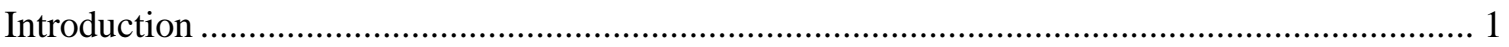

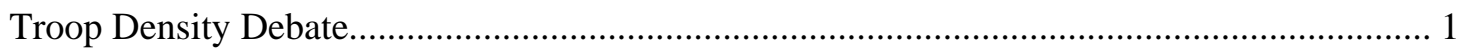

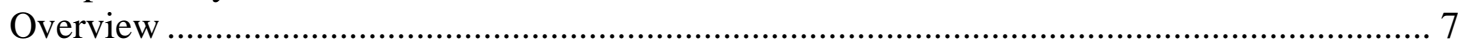

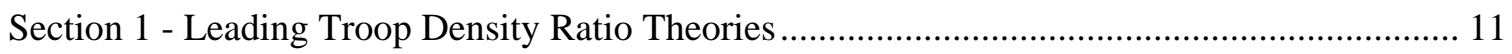

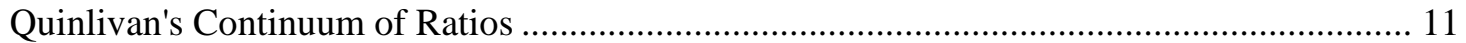

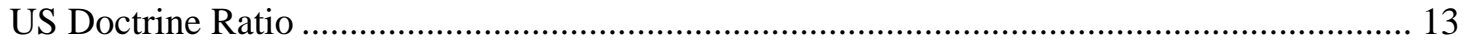

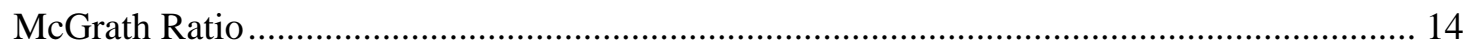

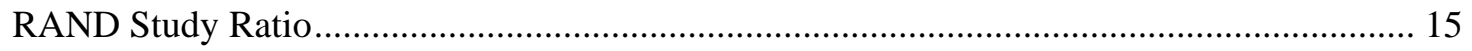

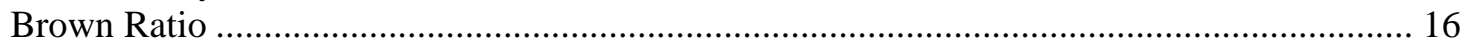

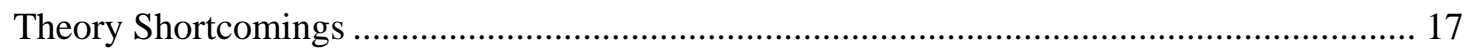

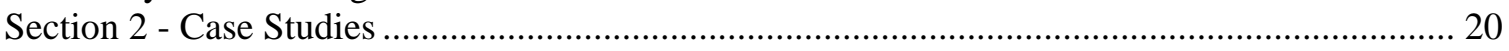

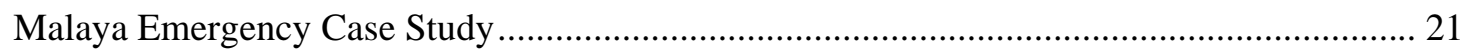

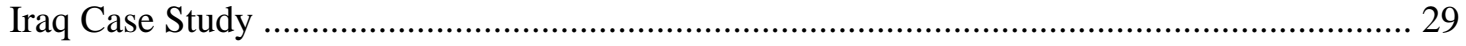

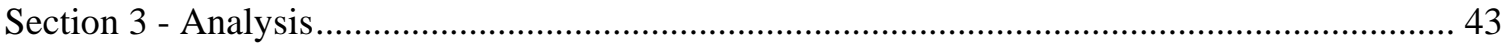

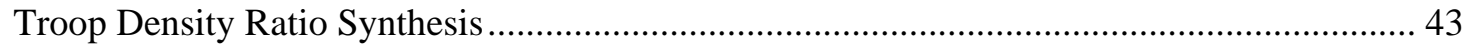

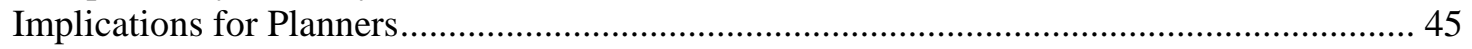

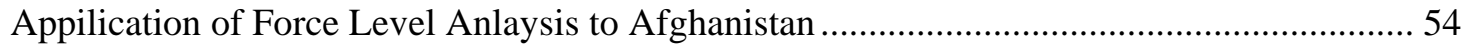

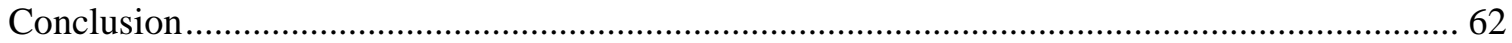

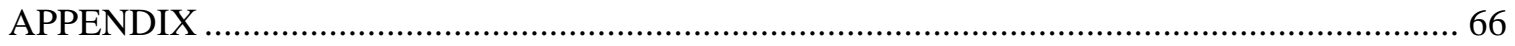

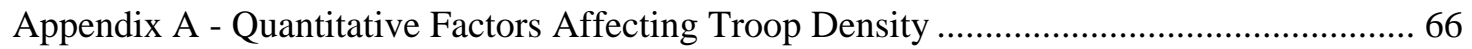

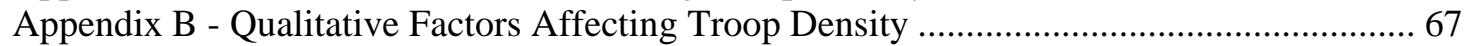

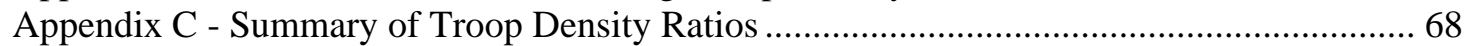

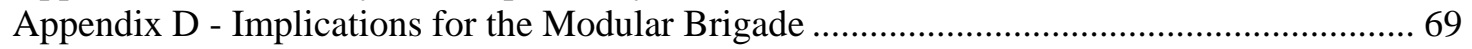

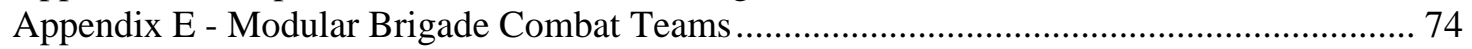

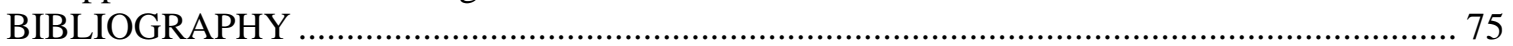




\section{Introduction}

It is a persistently methodical approach and steady pressure which will gradually wear the insurgent down. The government must not allow itself to be diverted either by countermoves on the part of the insurgent or by the critics on its own side who will be seeking a simpler and quicker solution. There are no short-cuts and no gimmicks.

-Sir Robert Thompson, Defeating Communist Insurgency: The Lessons of Malaya and Vietnam ${ }^{1}$

\section{Troop Density Debate}

As the War on Terrorism or Long War moves into its eighth year, one of the most intensely debated issues concerning the conduct of the war thus far has been over the level of troops committed to the effort. Military observers, policy makers, military officers, and media pundits have discussed this issue obsessively. ${ }^{2}$ For the Iraq Theater, the discussion over troop levels began in 2002 between military planners and senior Pentagon civilians during the war's initial planning. ${ }^{3}$ Then Secretary of Defense Donald Rumsfeld and other senior Pentagon civilians held deeply divergent viewpoints from the Army, particularly CENTCOM, who would execute the operation, over the level of forces required to defeat Saddam's regime. Rumsfeld strongly desired to follow the Afghanistan experience of using limited ground forces, focusing on

\footnotetext{
${ }^{1}$ Sir Robert Thompson, Defeating Communist Insurgency: The Lesson of Malaya and Vietnam (1966; repr., St. Petersburg, FL: Hailer Publishing, 2005), 171.

2 Margaret Warner, “Securing Iraq,” Online News Hour, August 22, 2003, a NewsHour with Jim Lehrer Transcript, http://www.pbs.org/newshour/bb/middle_east/july-dec03/iraq_8-22.html (accessed September 27, 2008); Stephen Budiansky, “Formula for How Many Troops We Need,” Washington Post, May 10, 2004, http://www.spokesmanreview.com/breaking/story.asp?ID=2149 (accessed September 29, 2008); Steve Bene, “Not Enough Troops in Iraq?,” Washington Monthly, January 9, 2005, http://www.washingtonmonthly.com/archives/individual/2005_01/005422.php (accessed September 27, 2008); John S. Brown, “Numerical Considerations in Military Occupations,” Army, April 2006, http://findarticles.com/p/articles/mi_qa3723/is_200604/ai_n17175276/pg_1 (accessed December 20, 2008); Robert Kagan and William Kristol, “Too Few Troops,” Weekly Standard 9, no.31, April 26, 2004, under "Resolve Alone Won’t Bring Success," http://www.weeklystandard.com/Content/Public/Articles/000/000/003/977ovnnr.asp?pg=2 (accessed February 16, 2009).

${ }^{3}$ Thomas E. Ricks, Fiasco: The American Military Adventure in Iraq (New York: Penguin Press, 2006), 41, 118; Michael R. Gordon and General Bernard E. Trainor, COBRA II: The Inside Story of the Invasion and Occupation of Iraq (New York: Pantheon Books, 2006), 28-29, 45-46, 53, 76-77, 95-98, 119.
} 
technology and precision targeting, and using proxy (Iraqi) forces. ${ }^{4}$ Meanwhile, CENTCOM planners and Lieutenant General David McKiernan, the commander of the ground forces, were more cautious and desired a larger force to sustain the invasion and to mitigate unforeseen events. $^{5}$

Likewise, senior Pentagon officials also believed that the occupation of Iraq after regime change could be done with limited forces, as they did not expect the collapse of Iraqi governance or a large-scale insurgency to take hold. ${ }^{6}$ In response to inquiries on the forces needed, then Deputy Defense Secretary Paul Wolfowitz stated to the House Budget Committee, "It is hard to conceive that it would take more forces to provide stability in post-Saddam Iraq than it would take to conduct the war itself." ${ }^{, 7}$ He also believed the security environment in Iraq would be benign, stating, "I am reasonably certain that they will greet us as liberators, and that will help us keep requirements down."8 Conversely, many CENTCOM planners anticipated that the troop levels for phase IV would be very significant, requiring a level of 275,000 US forces to occupy Iraq, plus assistance from the Iraqi military. ${ }^{9}$ Several uniformed military leaders, including the Army Chief of Staff General Eric Shinseki, the CENTCOM Commander General Tommy Franks, and General McKiernan desired a force level closer to the one outlined in CENTCOM's 1998

${ }^{4}$ Ricks, Fiasco, 41, 68.

${ }^{5}$ Gordon and Trainor, COBRA II, 95-97, 103-104.

${ }^{6}$ Dr. Donald P. Wright and Colonel Timothy R. Reese, On Point II: Transition to the New Campaign (Fort Leavenworth, KS: Combat Studies Institute Press, 2008), 171.

${ }^{7}$ Ricks, Fiasco, 98.

${ }^{8}$ Ibid.

${ }^{9}$ Gordon and Trainor, COBRA II, 29, 101-105; "POLO STEP,” The National Security Archive no. 214 (August 15, 2002), http://www.gwu.edu/ nsarchiv/NSAEBB/NSAEBB214/index.htm (accessed October 12, 2008). POLO STEP was CENTCOM's Iraq war plan briefed to the White House and Defense Secretary Rumsfeld in 2002 that reflect the planning for the size and timing of the invasion force and stabilization force. The plan identified a ground force requirement of 270,000 at the beginning of Phase IV and reduced to 5,000 within 18 months. Phase IV is a stage in an operation where the focus is changed from sustained combat operations to primarily stability operations. US Joint Forces Command, Joint Publication 5-0, Joint Operation Planning, (Suffolk, VA: United States Joint Doctrine Group, 2006), chap. 4, 33-37. 
Iraq OPLAN of 385,000. ${ }^{10}$ However, Rumsfeld desired a much smaller force, one he estimated near125,000 or less. ${ }^{11}$

The discussion shifted to the public realm with General Shinseki's testimony before the Senate Armed Services Committee in February 2003 when he stated that the occupation of Iraq would take "several hundred thousand soldiers." 12 Then after the fall of Baghdad and the cessation of major combat operations, the issue of force levels became an everyday topic as Iraq fell into disorder with a visible and growing insurgency by the late summer of $2003 .{ }^{13}$ The issue took center stage again in January 2007 when US President Bush addressed the Nation on changing the US strategy in Iraq. ${ }^{14}$ The President's New Way Forward strategy, which committed an additional 21,500 US forces, began an intense debate between those in Congress who supported the desire for a new strategy in Iraq, and those that called to cap the current levels of US forces deployed or for immediate troop withdrawal. ${ }^{15}$

10 “DESERT CROSSING,” The National Security Archive no.207 (July 22, 1999), http://www.gwu.edu/ nsarchiv/NSAEBB/NSAEBB207/index.htm (accessed October 12, 2008). DESERT CROSSING was CENTCOM's 1999 war-game that tested the feasibility and potential outcomes of an invasion of Iraq based upon OPLAN 1003-98. OPLAN 1003-98 was CENTCOM's plan for regime change in Iraq, which called for a force of 400,000 to invade and stabilize the country.

${ }^{11}$ Gordon and Trainor, COBRA II, 4.

${ }^{12}$ Ibid., 102.

${ }^{13}$ Ricks, Fiasco, 164, 184, 101, 122.

${ }^{14}$ George W. Bush, "President's Address to the Nation: New Way Forward in Iraq,” White House database online (January 10, 2007), http://www.whitehouse.gov/news/releases/2007/01/20070110-7.html (accessed September 27, 2008). President's New Way Forward strategy, more commonly known as the "Surge" strategy, came at a time when violence in Iraq, and particularly Baghdad, had overwhelmed the political gains made from the 2005 elections. The continued threat of sectarian violence and a deeply ingrained insurgency looked to block any chance of creating a stable democracy unless decisively averted. The new strategy's immediate focus was re-establishing security in Baghdad. To accomplish this, the President called for additional US forces to help Iraqis clear and secure neighborhoods to protect the population. The President's new Iraq strategy was rooted in six fundamental elements: Let the Iraqis lead; help Iraqis protect the population; isolate extremists; create space for political progress; diversify political and economic efforts; and situate the strategy in a regional approach.

${ }^{15}$ Michael Abramowitz and Robin Write, "Bush to Add 21,500 Troops In an Effort to Stabilize Iraq,” Washingtonpost.com, January 11, 2007, http://www.washingtonpost.com/wpdyn/content/article/2007/01/10/AR2007011002437.html (accessed October 2, 2008); James Phillips, “President Bush's New Way Forward in Iraq,” WebMemo no. 1304 published by The Heritage Foundation (January 11, 2007), http://www.heritage.org/research/MiddleEast/wm1304.cfm (accessed October 2, 2008); 
As insurgency activity increased and the need for a new strategy became apparent if the Coalition was to attain its objectives, the debates over force levels intensified and coalesced into two opposing arguments. ${ }^{16}$ The first camp, typified by Senator’s John McCain and Joe Lieberman, argued that the Coalition deployed to Iraq with insufficient forces to accomplish the number of post-conflict tasks required and more were needed to achieve success. ${ }^{17}$ This camp’s opinion was that force levels were not only insufficient to provide a secure environment throughout the country, a critical and necessary requirement for reconstruction to begin, but also insufficient to secure Iraq’s borders, protect its infrastructure, restore order, secure ammunition stockpiles, and secure weapons of mass destruction, if found. ${ }^{18}$ This lack of forces, and subsequent security, not only provided an opportunity for the insurgency to grow, but also increased the risk of the country descending into chaos. ${ }^{19}$ As the CENTCOM commander, General Abizaid's statement during his 2006 Senate and House Armed Services Committees testimony clearly framed this opinion:

General Shinseki was right that a greater international force contribution, U.S. force contribution and Iraqi force contribution should have been available immediately after major combat operations. I think you can look back and say that more American troops would have been advisable in the early stages of May, June, July. ${ }^{20}$

Kathy Kiel and Bill Nichols, “Democrats Reject Bush’s 'Way Forward', USA Today, January 11, 2007, http://www.usatoday.com/news/washington/2007-01-10-dems-bush-iraq_x.htm (accessed October 2, 2008).

${ }^{16}$ Carter Malkansian, "Did the Coalition Need More Forces in Iraq? Evidence from Al Anbar," Joint Force Quarterly, no.46 (July 2007): 120-126.

${ }^{17}$ Michael R. Gordon and Mark Mazzetti, “General Warns of Risks if Iraq if G.I.’s are Cut,” New York Times, November 16, 2006, http://www.nytimes.com/2006/11/16/world/middleeast/16policy.html?_r=2 (accessed September 27, 2008); Michael Bowman, "US Legislators Debate Resolution Opposing Troop Surge in Iraq” (January 21, 2007), http://www.globalsecurity.org/wmd/library/news/iraq/2007/01/iraq-070121-voa01.htm (accessed September 29, 2008); Kiel and Nichols, "Democrats Reject Bush’s 'Way Forward'.”

${ }^{18}$ US Department of the Army, FM 3-07, Stability Operations (Washington, D.C.: Headquarters United States Army, 2008), 2-9-2-10; Gordon and Trainor, COBRA II, 104.

${ }^{19}$ Malkansian, “Did the Coalition Need More Forces in Iraq?”; Ricks, Fiasco, 99, 101-102, 120.

${ }^{20}$ Gordon and Mazzetti, “General Warns of Risks if Iraq if G.I.’s are Cut.” Article recounts General Abizaid's testimony about troop levels in Iraq. GEN Abizaid made it clear he did not endorse the phased troop withdrawals being proposed by Democratic lawmakers, and that the number of troops may 
The basis for this camp's argument is the commonly cited "standard ratio" for a counterinsurgency force density that states 20 security force personnel per 1000 civilian population is required to secure them from insurgents. ${ }^{21}$ Through a simple calculation, a planning figure of over 500,000 security forces is determined from an Iraqi population of approximately 25.5 million. ${ }^{22}$ With a peak force of 183,000 US and Coalition forces and approximately 54,000 operational Iraqi Security Forces (ISF) in December of 2005, simple mathematics substantiates this camp’s position that there were insufficient forces. ${ }^{23}$

The second camp, typified by Congressman John Murtha and Senator John Kerry, tend to agree with the first camp’s position that troop levels were insufficient for securing Iraq, but they disagreed in escalating US force presence. ${ }^{24}$ This argument held that the large presence of US forces in Iraq presented an image of occupation, which only worsened the situation by fueling the

need to increase to improve the training of the Iraqi Army. The article also stated that GEN Abizaid "publicly stated for the first time that the American position in Iraq had been undermined by the Bush administration's decision not to deploy a larger force to stabilize the country in 2003.”

${ }^{21}$ Malkansian, “Did the Coalition Need More Forces in Iraq?” Term security forces is defined in FM 3-24, Counterinsurgency, as including the host nation's military and police forces as well as foreign counterinsurgents. US Department of the Army, FM 3-24, Counterinsurgency (Washington, D.C.: Headquarters United States Army, 2006), 1-13. The "standard" COIN troop density ratio is the commonly cited ratio provided by James Quinlivan in his work "Burden of Victory.” James T. Quinlivan, "Burden of Victory: The Painful Arithmetic of Stability Operations,” RAND Review 27, no. 2 (Summer 2003), http://www.rand.org/pubs/corporate_pubs/CP22-2003-08/ (accessed September 29, 2008).

${ }^{22} 25.5$ million is the planning figure used for pre-combat operations in Iraq, as cited by many sources including Malkansian, "Did the Coalition Need More Forces in Iraq?”; John J. McGrath, "Boots on the Ground: Troop Density in Contingency Operations," Global War on Terrorism Occasional Paper 16 (Fort Leavenworth, KS: Combat Studies Institute Press, 2006), 120; Quinlivan, "Burden of Victory.”

${ }^{23}$ Michael E. O’Hanlon, "Iraqi Index: Tracking Variables of Reconstruction and Security in PostSaddam Iraq,” April 2006 (Washington D.C.: The Brookings Institute, 2008), 20, 25, http://www.brookings.edu/saban/iraq-index.aspx (accessed October 13, 2008). This calculation produces a force ratio of 9.3. However, this level was not maintained as Coalition force levels dropped significantly between February 2006 and May 2007. The numbers of ISF present, trained, equipped, and operational, along with overall effectiveness is open to interpretation. Although an estimated 223,700 ISF were on hand in December 2005, in February 2006 only 54,000 were estimated to be operational and in the lead.

${ }^{24}$ Kiel and Nichols, “Democrats Reject Bush’s ‘Way Forward””; James Joyner, “John Murtha Calls for Iraq Pullout,” Outside the Beltway.com (November 17, 2005), http://www.outsidethebeltway.com/archives/john_murtha_calls_for_iraq_pullout/ (accessed October 2, 2008). 
insurgency. ${ }^{25}$ It was also thought that a large US presence would alienate Iraqis who were neutral or pro-Coalition. As Congressman Murtha stated, "Our troops have become the primary target of the insurgency. They are united against U.S. forces and we have become a catalyst for violence.” ${ }^{26}$ This camp also believed that a reduction in US forces would motivate, if not force, the Iraqi security forces to take greater responsibly for security and that a political solution rather than a military solution was required to achieve stability. ${ }^{27}$ A reduction in forces would also increase the pressure on Iraq's government and sectarian leaders to make the necessary compromises to quell the violence. ${ }^{28}$ Finally, an increase in US forces would undermine US pressure for more support from the "Coalition of the Willing."29

In the view of those in this second camp, a more indirect approach was needed. Some called for US and Coalition forces to maintain small numbers of advisors embedded with Iraqi forces to assist them in securing the population and conducting counterinsurgency operations. ${ }^{30}$ Others proposed leaving no troops in Iraq, but return to an over-the-horizon military posture with quick reaction forces to defend the Persian Gulf and more robust regional diplomacy. ${ }^{31}$

Although both arguments have merit, the purpose of this monograph is not to justify one or the other, but instead to develop a deeper understanding of the issues surrounding the required troop levels for counterinsurgency operations. With counterinsurgency, or COIN operations being complex as the environment constantly adapts to the numerous political, socioeconomic, and

${ }^{25}$ Malkansian, "Did the Coalition Need More Forces in Iraq?”

${ }^{26}$ Joyner, “John Murtha Calls for Iraq Pullout.”

${ }^{27}$ Kiel and Nichols, “Democrats Reject Bush’s 'Way Forward'.”

${ }^{28}$ Bowman, "US Legislators Debate Resolution Opposing Troop Surge in Iraq."

${ }^{29}$ Wright and Reese, On Point II, 167.

${ }^{30}$ Malkansian, "Did the Coalition Need More Forces in Iraq?”

${ }^{31}$ Flynt Leverett, “A 'Formula' for Lifting America’s Standing in the Middle East,” Council on Foreign Relations (October 12 2007), http://www.cfr.org/publication/14471/leverett.html (accessed September 29, 2008). 
military variables, it is often difficult to determine the optimum force size required to defeat an insurgency and restore order. ${ }^{32}$

\section{Overview}

The debate mentioned above, to some degree particularly in military circles, is a symptom of the lack of doctrine or established guidance on the subject. Despite having little current US Army irregular warfare doctrine to reference, the doctrine that is published provides very little guidance in determining the appropriate force level desired for successful operations. ${ }^{33}$ FM 3-24, Counterinsurgency, provides the most explicit guidance with a planning figure of 20-25 security forces for every 1000 inhabitants (called troop density-the number of security forces per population size), yet states that every situation will be unique and any fixed ratio will not guarantee success. ${ }^{34}$ Although it is true that each situation is unique, and it is impossible to make a direct causal connection between force levels and success since war is a human endeavor with inherent friction and unpredictability, there is a strong correlative relationship between the two. ${ }^{35}$ In COIN, numbers do matter. As James Quinlivan, a prominent theorist on troop density in

\footnotetext{
32 Brown, "Numerical Considerations in Military Occupations."

${ }^{33}$ Included are FM 3-24 Counterinsurgency (2006), FM 7-98 Operations in a Low-Intensity Conflict (1992), FM 90-8 Counterguerrilla Operations (1986), FM 3-07 Stability Operations (2008), and the 1940 US Marine Corps Small Wars Manual. The Small Wars Manual states that a force assigned a small wars mission should be tactically and administratively self-sustaining unit, such as the Fleet Marine Force in the Marine Corps, or an Army brigade as the basic organization. The force composition will depend upon its mission, the forces available, and character of the operations, sec. III, 43-44. FM 3-24 Counterinsurgency has two paragraphs on forces needed, 1-67 and 1-68. FM 7-98 Operations in a LowIntensity Conflict and FM 90-8 Counterguerrilla Operations provide only concepts. These include that successful operations depend on the commander using his available assets to maximize strengths and minimize weaknesses, but neither provide any specific ratios for planning. FM 3-07 Stability Operations only provides concepts that include force tailoring and task organizing to meet the requirements as determine by the joint force commander and specific stability missions, 4-12. FM 3-0 Operations (2008) is also vague on force levels needed, stating that commanders need to "consider available troops and support when determining the resources required to accomplish a mission-a troop-to-task analysis," 5-7.

${ }^{34}$ US Army FM 3-24, Counterinsurgency, 1-13.

${ }^{35}$ Wesley C. Salmon, Causality and Explanation (New York: Oxford University Press, 1998), 7-8; US Army FM 3-07, Stability Operations, 4-1.
} 
stability operations wrote, "No one has discovered successful stabilization strategies that avoid large troop commitments while trying to bring order to large populations.”36

Numbers matter because the counterinsurgent must have adequate resources available to establish and maintain widespread security and to protect the population against insurgent violence. Security is the essential bedrock on which all other endeavors and operations across a campaign are built, including governance, provision of essential services, and stimulation of economic development. ${ }^{37}$ In addition to safeguarding the population, the COIN force must also have adequate force levels to conduct full spectrum operations (FSO), which includes simultaneous operations to defeat irreconcilable insurgents, secure the border, protect key infrastructure, and train host-nation (HN) security forces, to name a few of the key tasks. ${ }^{38}$ Although security is necessary, in fact critical, it is insufficient for achieving COIN objectives by itself. Counterinsurgents also require the resources to adapt a wide variety of civil-military initiatives to marginalize the insurgents politically, socially, economically, and militarily. This marginalization requires a stable environment where upon the government and international partners can leverage all aspects of national power to eliminate the underlying causes of the insurgency, and strengthen the government's institutions to reinforce its legitimacy in the eyes of its people. ${ }^{39}$

\footnotetext{
${ }^{36}$ Quinlivan, "Burden of Victory.”

${ }^{37}$ US Army FM 3-24, Counterinsurgency, 1-13, 1-23, 5-2.
}

${ }^{38}$ US Army FM 3-24, Counterinsurgency, 1-29, table 1-1; FSO defined as “The Army's operational concept: Army forces combine offensive, defensive, and stability or civil support operations simultaneously as part of an interdependent joint force to seize, retain, and exploit the initiative, accepting prudent risk to create opportunities to achieve decisive results. They employ synchronized action-lethal and nonlethal-proportional to the mission and informed by a thorough understanding of all variables of the operational environment. Mission command that conveys intent and an appreciation of all aspects of the situation guides the adaptive use of Army forces." US Department of the Army, FM 3-0, Operations (Washington, D.C.: Headquarters United States Army, 2008), G-7.

${ }^{39}$ Ibid., 1-1, 1-13. 
The question then, like the debate mentioned earlier, centers on what standard or doctrine to which these two conflicting camps are comparing their data. A subsequent question is how can an operational or tactical level planner, who is anticipating ground-force involvement in a COIN operation, determine the right force level. Such endeavors require further planning guidance and analysis beyond the number of security forces based on population size. This analysis must also consider the operational environment in determining the required force density. ${ }^{40}$ Only through a holistic analysis, based on each situation’s unique circumstances, will policy makers and commanders have sound justification for the proposed force density recommendations.

Some of this analysis and understanding is certainly conducted during design and the planning processes. ${ }^{41}$ Commanders and staffs intuitively and analytically assess the environment and key tasks they will have to conduct to gain a feel for the level of forces required. During the intelligence preparation of the battlefield (IPB), the threat and effects of the environment are also analyzed and evaluated, supporting the development of staff estimates and the planning processes. ${ }^{42}$ While these processes are critical in gaining an understanding of the problem, they do not provide a complete framework for determining force levels. Specifically, there remains a gap between theory and practice. Therefore, the purpose of this work is to analyze the relevant theories against case studies to provide a comprehensive analysis of the critical qualitative and quantitative factors in determining a valid force size for conducting COIN operations in a given environment.

${ }^{40}$ US Army FM 3-0, Operations, 1-1, 1-5.

${ }^{41}$ School of Advanced Military Studies, “Art of Design: Student Text Version 1.0,” (September 24, 2008), prepared by Booz Allen Hamilton for US Army Training and Doctrine Command, 18-19; US Joint Forces Command Joint Publication 5-0, Joint Operation Planning, chap. 3, sec. C and D; US Department of the Army, FM 5-0, Army Planning and Orders Production (Washington, D.C.: Headquarters United States Army, 2005), chap. 3.

${ }^{42}$ US Department of the Army, FM 34-130, Intelligence Preparation of the Battlefield (Washington, D.C.: Headquarters United States Army, 1994), 1-1-1-6. FM 34-130 does provide planning force ratios for major combat operations on page B-38, but not for other types of operations. FM 34-130 also contains IPB analysis for operations other than war in chapter 6, but it is very rudimentary. 
The methodology utilized for this study includes quantitative and qualitative analysis of case studies to examine the size of security forces used in successful COIN operations. ${ }^{43}$

Quantitative analysis of the case studies is used to compare the security force size employed to the population size in order to determine a historical force density ratio. The qualitative analysis of the case studies is used to identify and assess the specific operational environment factors that influenced a particular force density used. The critical operational environmental factors for this study, as determined by the author, are geography, demographics, nature of the conflict, culture, political situation, the directed mission, and time. By examining these factors, planners can more accurately adjust the force density to the meet the needs of a specific situation.

The selected case studies include the Malayan Emergency (1948-1960), often cited as the most successful COIN operation conducted by a 20th-century Western power, and Iraq (2003present). ${ }^{44}$ To date, Iraq is currently making significant progress towards stability and could be the first successful US COIN campaign since its strategic defeat in Vietnam. ${ }^{45}$ Both cases are well-documented, required large forces over several years, and are recent operations (post WWII). ${ }^{46}$ The events examined in the historical context of these case studies will enable a better understanding of the relationship between the operational environment factors and the force

43 Definition of success is taken from a RAND study, where the term is defined as: "the establishment of stability and a rule of law. A stable environment is one in which violence-prone groups such as insurgents or criminals are subordinated to legitimate governmental authority, reintegrated into society, or defeated. A stable environment also includes the population being free from major threats to their safety and where national and international actors are able to rebuild political, economic, and other key governance institutions. Seth G. Jones et al., "Establishing Law and Order After Conflict,” RAND Corporation monograph series (Santa Monica, CA: RAND Corporation, 2005), 2, http://www.rand.org/pubs/monographs/2005/RAND_MG374.pdf (accessed September 19, 2008).

${ }^{44}$ Wright and Reese, On Point II, 170.

${ }^{45}$ Lewis Sorley, A Better War: The Unexamined Victories and Final Tragedy of America's Last Years in Vietnam (Orlando, FL: Harvest Book, Harcourt, Inc.), 380.

${ }^{46}$ Post WWII is important due to the technological advancements for both the COIN force and insurgents. These include wireless communications for improved command, control and coordination, mechanized and motorized movement and maneuver of forces, and increased precision firepower. Mass media and the Internet have become significant enablers for conducting information operations to a global audience. The Internet also provides the insurgent access to a global community and support base. 
density ratio. Finally, this analysis will be applied to Afghanistan, as it provides a contemporary operation that is currently reviewing its force levels and strategy, and is an example of what future environments may involve. Through analyzing these case studies and force ratio theories, this monograph will gain a deeper understanding of the issues surrounding force levels in the course of addressing the following questions:

1. What is the historical foundation for the 20 security forces per 1000 inhabitants ratio? What are the current force ratio theories for COIN operations?

2. How do critical operational environment factors such as demographics, geography, and culture affect troop density? What force level is needed to secure a population?

3. What are the significant implications from past COIN operations for today's planners? Is the doctrinal force density ratio of 20 security forces per 1000 inhabitants adequate to base force level planning for COIN operations for today’s modular force structure?

\section{Section 1-Leading Troop Density Ratio Theories}

Many troop density theories have been suggested, from troops to insurgent, troops to population, and troops to terrain (per square mile). However, from the Army's experience in current operations and its recent COIN doctrine (FM 3-24, Counterinsurgency), it is understood at the tactical and operational level that the population's protection and welfare must be foremost in order to gain their support and restore the legitimacy of the government. ${ }^{47}$ Therefore, recent theories in developing planning estimates have been based upon the population's size to determine the required force levels.

\section{Quinlivan's Continuum of Ratios}

${ }^{47}$ US Army FM 3-24, Counterinsurgency, 1-21, 1-28. Current US operations include IRAQI FREEDOM in Iraq and ENDURING FREEDOM in Afghanistan. 
James Quinlivan, a military analyst and senior mathematician at the RAND Corporation, provided a comprehensive and often-cited theory of troop densities for contingency operations (accumulative term he uses for operations other than major combat). He is the most prolific theorist and author on troop densities for contingency operations and to date has produced the most comprehensive and well-known theory on troop density with his work, "Force

Requirements in Stability Operations.” Other authors continuously cite this article and his article "Burden of Victory” as the basis for their proposed force levels.

He promulgates a continuum of force density levels, based on three levels of violence or threat intensity. At the low end of the scale, such as peaceful populations that require only day-today law enforcement, a force ratio between one and four security forces per thousand of population is required. ${ }^{48}$ This requirement is usually met utilizing a nation's police forces. The United States for example, uses an average of 2.5 state and local full-time police officers per thousand residents. ${ }^{49}$ The middle range has a force ratio of between four and ten security forces per thousand of population. This level requires police and military forces to stabilize civil unrest. Examples Quinlivan includes are India’s operations in the Punjab (1978-1993) with a ratio of 5.7 per thousand and US operations in the Dominican Republic (1965) with a ratio of 6.6 per thousand. ${ }^{50}$ A better-known example is the occupation of Japan (1945-1950) at the end of World War II, which the US conducted with a ratio of almost five security forces per thousand

\footnotetext{
${ }^{48}$ James T. Quinlivan, “Force Requirements in Stability Operations," Parameters, US Army War College Quarterly (Winter 1995): 59-69, http://www.carlisle.army.mil/usawc/parameters/1995/quinliv.htm (accessed September 29, 2008).

${ }^{49}$ Based on data from US Census Bureau with a total US population estimate of 293 million in 2004, and the US Bureau of Justice stating there were 731,903 state and local full-time sworn officers in 2004. Year 2004 was selected since it was the most recent date for law enforcement statistics. US Bureau of the Census, "Table 8: Annual Estimates of the Population of the United States” (July 2004), http://www.census.gov/popest/states/NST-ann-est2004.html (accessed October 2, 2008); US Bureau of Justice Statistics, "Law Enforcement Statistics” (2004), http://www.ojp.usdoj.gov/bjs/lawenf.htm (accessed October 2, 2008). The ratio of 2.5 police is an average for the nation, while major cities typically use more police forces with an average of 4.1. McGrath, "Boots on the Ground," 79.

${ }^{50}$ Quinlivan, "Force Requirements in Stability Operations,” 59-69.
} 
inhabitants. ${ }^{51}$ At the high end of the continuum, where insurgency or major unrest exists and external assistance is usually required, the security requirement is much higher with a force ratio of 10 or more per thousand of population. Here, large numbers of conventional military forces along with indigenous forces are required. Quinlivan cites the British examples of the Malayan Emergency (1948-1960) and Northern Ireland (1969-2007), both of which used 20 military forces per 1000 inhabitants at their peak deployments, and both achieved successes. ${ }^{52}$

With its 1995 publication, Quinlivan’s theory utilizing the ratio of 20 security forces per thousand inhabitants (the 20:1000 ratio) has become the "usually cited standard for all contingency operations" and is often considered the minimum effective troop density ratio. ${ }^{53}$ This ratio was used again during NATO’s Implementation Force deployment to Bosnia (1995-present) with the multinational force having a troop density of 21.8 per thousand inhabitants at its peak. ${ }^{54}$ The UN-sanctioned multinational operation to Kosovo (1999-present) likewise followed this troop density with a ratio of 21.1 military forces per thousand inhabitants. ${ }^{55}$

\section{US Doctrine Ratio}

${ }^{51}$ McGrath, “Boots on the Ground,” 32.

${ }^{52}$ Quinlivan, "Force Requirements in Stability Operations,” 59-69.

${ }^{53}$ McGrath, "Boots on the Ground," 1, 94. Many military observers and civilian journalists including James Quinlivan himself cite the 20 to 1000 ratio as the "standard." Quinlivan, "Burden of Victory”; US Army FM 3-24, Counterinsurgency, 1-13.

${ }^{54}$ Bosnia troop density is questionable since two conflicting troop density ratios were found based on different Bosnia population estimates. McGrath used a population of 4 million, based on CIA World Factbook, "Boots on the Ground," 48, while Quinlivan used a population of 2.6 million, based on US Bureau of the Census, International Data Base, "Burden of Victory." The last official census was complete in 1991 with a population of 4.4 million, so both estimates are attempting to account for population change caused by the Bosnia War (1992-1995). In 1996, Bosnia’s state Health Protection Office declared the casualty data during Bosnia's war to be 278,000 killed or missing, and 1.37 million displaced. Bosnia's state Health Protection Office, “Bosnia-Herzegovina’s War Casualties Estimation” (March 29, 1996), http://www.hdmagazine.com/bosnia/census.html (accessed October 1, 2008). With this data, a new population 2.75 million is calculated, which produces a troop density ratio of 21.8 per thousand inhabitants. The point is still valid that a troop density of approximately 20 per thousand was used.

${ }^{55}$ McGrath, "Boots on the Ground," 57. The same population inaccuracies are also seen with Kosovo, but not to the extent as Bosnia. 
At the core of COIN operations is the struggle for the population's support, which entails providing a stable and secure environment while building capacity and legitimacy of the HN government. ${ }^{56}$ This indicates that the number of troops required must be relative to the size of the population they are to protect. ${ }^{57}$ Therefore, previous attempts to base force requirements upon the number of insurgents, such as a ratio of 10 to 15 military forces to every insurgent is misleading and insufficient. ${ }^{58}$ The problem with this method is that it is very difficult to determine an accurate number of insurgents a force may face. A significant advantage insurgents possess is their anonymity, specifically among an ambivalent population. In addition, the estimated size of the insurgent faction will continuously fluctuate, making this ratio nebulous at best. Targeting insurgents is also problematic because by not knowing their size; it is difficult to measure success in killing or detaining them, while the population is still exposed to their intimidation.

For these reasons, FM 3-24, Counterinsurgency, prescribes that troop density based upon population be used as a force requirement gauge. It states, "Most density recommendations fall within a range of 20-25 counterinsurgents for every 1000 residents in an AO [Area of Operations]. Twenty counterinsurgents per 1000 residents is often considered the minimum troop density required for effective COIN operations.”59 Therefore, current US doctrine reflects the troop density theory based on recent British and American contingency operations and the Quinlivan ratio stated above. ${ }^{60}$

\section{McGrath Ratio}

${ }^{56}$ US Army FM 3-24, Counterinsurgency, 1-21, 1-28.

${ }^{57}$ Quinlivan, “Force Requirements in Stability Operations,” 59-69.

${ }^{58}$ US Army FM 3-24, Counterinsurgency, 1-13.

${ }^{59}$ Ibid.

${ }^{60}$ According to FM 3-24, Counterinsurgency, source notes, this ratio was taken from McGrath's work, "Boots on the Ground," 1,6n1. However, the 20-25 per 1000 ratio in McGrath's work is cited from James Quinlivan's work as noted above. Interestingly, McGrath proposes his own ratio of 13.26 per 1000 for contingency operations, which the writers of FM 3-24 rejected. 
One author that does not subscribe to the troop density ratio of 20 per thousand, however, is John McGrath. McGrath is a retired Army Reserve Officer and historian for the US Army Center of Military History, and was asked to conduct a study for the Combat Studies Institute at Fort Leavenworth to determine a historically accurate troop density ratio for military planners in contingency operations (his term for all operations other than major combat operations) ${ }^{61}$ For his analysis, he examined seven historical case studies of military operations that supported his classification criteria of successful contingency operations, including the Philippines, Germany (both military and police occupations), Japan, Austria, Malaya, Bosnia, and Kosovo. He also researched the police forces used in major US cities, as police are a critical component for providing a secure environment for the populace. ${ }^{62}$ From his analysis of these case studies, he proposed a ratio of 13.26 soldiers per thousand inhabitants, with one-third of the force devoted to police functions. ${ }^{63}$

\section{RAND Study Ratio}

Another theory that departs from 20:1000 "standard" is provided by a team of RAND Corporation analysts who published a series of monographs focused on nation-building. ${ }^{64}$ As part of their detailed analysis of reestablishing internal security institutions during nation-building missions, an important aspect of their research was the size of security forces needed in postconflict law and order operations. The case studies examined the reconstruction of security sector efforts in Iraq, Afghanistan, and Kosovo, and compared them to cases including Panama, El

\footnotetext{
${ }^{61}$ McGrath, "Boots on the Ground,” 1-4, table 1.

${ }^{62}$ US Army FM 3-07, Stability Operations, 2-10; McGrath, “Boots on the Ground,” 84.

${ }^{63}$ McGrath, "Boots on the Ground,” 106.

${ }^{64}$ Nation-building operations are defined as activities commonly known as post-conflict reconstruction interventions, stabilization operations, peace support operations, and peace building endeavors. These operations underpin a transition to peace through the deployment of international military forces and include comprehensive efforts to rebuild the security, political, and economic sectors. These either occur after a major combat operation and can include significant violence and insurgent activity, or
} 
Salvador, Somalia, Haiti, Bosnia, and East Timor. ${ }^{65}$ They synthesized that "large numbers of troops are particularly critical for defeating and deterring insurgents; patrolling borders; securing roads; combating organized crime; and conducting general law enforcement functions such as policing streets."

The RAND study concludes that a level of at least 10 soldiers per thousand inhabitants is necessary for success, especially where there is potential for severe instability. The authors also state that international police forces are critical to overall security and operations will likely require at least 1.5 police per thousand inhabitants. Finally, domestic police forces must be trained and operational, with a level of at least two per thousand inhabitants. Adding these minimum force levels together, a security force ratio of 13.5 per thousand inhabitants emerges to conduct the critical functions of imposing order and building internal security force capacity. ${ }^{67}$

\section{Brown Ratio}

Another contributor to the subject of troop levels is Brigadier General (Ret.) John Brown. BG Brown, who served as the Chief of Military History at the US Army Center of Military History, published an article in Army where he cited a ratio of one soldier for every 100 inhabitants (10:1000) as the US historical average for occupations. The significance of Brown's article is that it supports the RAND study ratio of 10:1000 as a minimum level, excluding the police. Brown also examined troop density from a historical perspective of US occupations

occur in a benign security environment with little or no resistance. Jones, "Establishing Law and Order After Conflict,” 5.

${ }^{65}$ Ibid., iii.

${ }^{66}$ Ibid., 19.

${ }^{67}$ Ibid., xiii, 202, 212. 
(Japan, Italy, Nicaragua, Philippines, Haiti, Germany, Austria, Korea, Bosnia, and Kosovo) to provide a US historical ratio of “one in hundred 'average’.,"68

\section{Theory Shortcomings}

Although useful in analyzing past contingency operations, there are three critical shortcomings in the theories mentioned. These include the categorization of the case studies selected, the exclusion of HN forces, and the treatment of all populations as being equal.

The first critique is that because of the broadness of the categorization terms used, with McGrath and Quinlivan using contingency operations, the Rand Study’s nation-building operations, and Brown's occupations, they have combined case studies that contained military operations across several operational themes, which slanted their results. This is significant since each operational theme directly affects the levels of resources, including force levels, needed to conduct them. ${ }^{69}$

The US Army’s revised capstone doctrinal publication, FM 3-0, Operations, provides five operational themes that describe and classify the character of the dominate operation being conducted. These themes, listed as peacetime military engagement, limited intervention, peace operations, irregular warfare, and major combat operations, have implications for taskorganization, resource allocation, and tactical task assignment. ${ }^{70}$ It is also critical to understand that each operational theme corresponds broadly to a range along the spectrum of conflict, as indicated in figure $1 .^{71}$ Therefore, each theme potentially confronts a different level of violence and requires different force packages. This conclusion logically implies that military operations

${ }^{68}$ Brown, "Numerical Considerations in Military Occupations.” Although Brown provides a historical average, it may not be accurate since he does not include all US occupations. Glaring exclusions include the occupation of the American West and Iraq.

${ }^{69}$ US Army FM 3-0, Operations, 2-3.

${ }^{70}$ Ibid., 2-3-2-4, table 2-1.

${ }^{71}$ Ibid., 2-4-2-5, fig. 3-4. 
under different operational themes should not be categorized into a collective group when comparing resources.

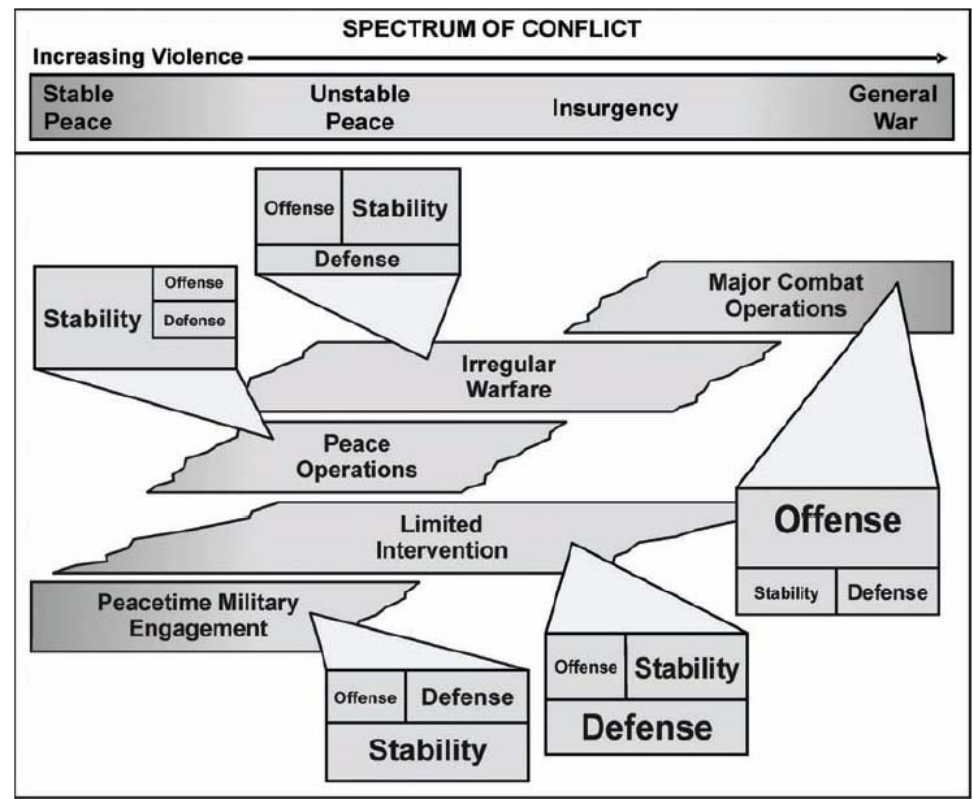

Figure 1. Examples of the elements of FSO within operational themes ${ }^{72}$

This concept also holds true when examining military operations from the aspect of the US Army's operational concept of FSO. FSO requires continuous, simultaneous combinations of offensive, defensive, and stability tasks across all operational themes. ${ }^{73}$ However, different combinations of the elements of FSO generally characterize each operational theme, as depicted in figure 1. For example, stability operations is the prominent full spectrum element for the operational theme of peace operations, while stability, offense, and defense are more balanced for the operational theme of irregular warfare. This aspect is critical in examining force density. Peace operations are conducted to keep violence from spreading, reduce tensions among factions, and to create a safe and secure environment for reconciliation and rebuilding; therefore, fewer

\footnotetext{
${ }^{72}$ Ibid., fig. 3-4.

${ }^{73}$ Ibid., 3-1, 3-20.
} 
forces are needed for offensive and defensive operations while the majority of the force focuses on stability operations. ${ }^{74}$

In comparison, irregular warfare, which contains COIN operations, is conducted when there is a violent struggle between state and non-state actors for legitimacy and influence over the population. ${ }^{75}$ Increased force levels are needed to conduct offensive and defensive operations to set the conditions for stability operations, which require the absence of major threats to friendly forces and the populace. ${ }^{76}$ However, to gain or retain the support of the population, stability operations cannot wait until the other operations are complete; all elements of FSO should be conducted simultaneously, or close to it. This is why COIN is manpower intensive. COIN forces must conduct widespread stability and defensive operations to provide and maintain order and security for the civilian populace, the most critical aspect of COIN, while also conducting offensive operations to defeat the insurgency. ${ }^{77}$ Therefore, in analyzing the historical context of an operation, or looking to future conflicts, it is important to establish the operational theme within which the major operation is taking place.

In analyzing the results of the previously stated theorists, the broad categorizations used disposed them to combine operations from different operational themes. The result was a disproportionally high selection of peace operations to irregular warfare operations in their analysis. ${ }^{78}$ Consequently, the majority of the cases selected experienced lower levels of violence and required fewer forces, resulting in a lower overall troop density ratio. Subsequently, most theorists' ratios are therefore significantly lower than the twenty per thousand "standard.” By

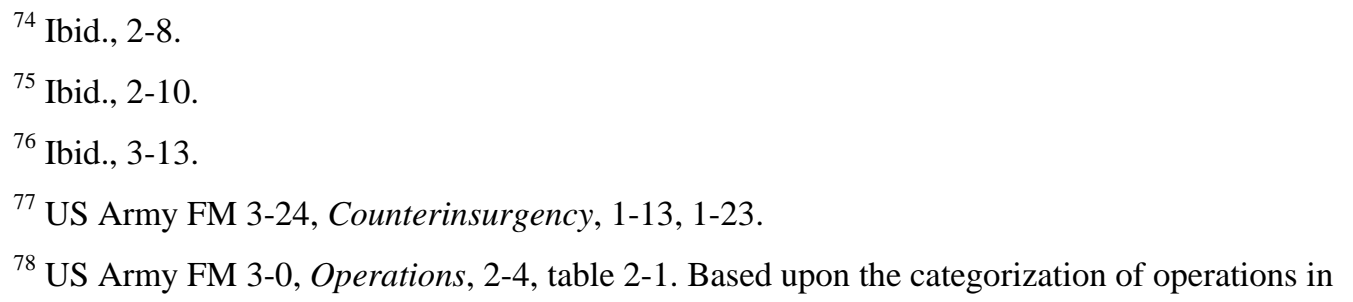

${ }^{78}$ US Army FM 3-0, Operations, 2-4, table 2-1. Based upon the categorization of operations in table 2-1, the proportion of peace operations to irregular warfare operations selected is 5:2 for McGrath, 6:3 for the Rand Study, and 7:3 for Brown. 
examining only irregular warfare operations and COIN cases in particular, the force ratio will increase, as this study will show.

Second, some of the case studies significantly discounted portions of the HN security forces used from their calculations, specifically the police forces. Although HN forces may not be as proficient as external forces, they have distinct advantages that provide critical capabilities to a COIN effort. Therefore, their exclusion discounts a significant portion of the COIN force and leads to a lower force ratio when compared to the population.

A third critique is that the population size-based ratios stated above tend to treat all populations as equal. They do not account for the social, ethnic, cultural, and demographical challenges found in large populations. These qualitative variables are critical, as force levels alone do not guarantee success. One only has to examine the Vietnam conflict, where the US and the Free World Military Assistance Forces fielded almost one soldier for every 16 Vietnamese with an unsatisfactory conclusion. ${ }^{79}$

\section{Section 2-Case Studies}

This section will provide an overview of two case studies for examining the troop densities used. In doing so, the case study analysis will determine two critical points of time and associated force levels. The first temporal distinction is when the insurgency was initially recognized as a serious threat and the corresponding COIN force level. The second is when the COIN force began achieving sustainable success over the insurgents and the corresponding force level. The quantitative analysis includes the size of the population and the number of security forces required to provide stability and pacify the country. The qualitative factors examine the impacts of the operational environment upon the troop density used.

\footnotetext{
${ }^{79}$ Sorley, A Better War, 31-32. US and FWMAF in total fielded over 1.1 million men in 1969, with a South Vietnam population of approximately 16 million, produces a ratio of nearly 69:1000. The US alone deployed 543,000, its highest troop level in 1969. However, Vietnam was not a COIN-only conflict.
} 


\section{Malaya Emergency Case Study}

The Malayan Emergency is critical to this study since it still stands as an exemplary

model for COIN operations because of the effective techniques used and the success it

achieved. ${ }^{80}$ A striking aspect of this operation was the protracted strategy adopted and executed through a unified effort of a wide range of civil and military programs. This was primarily a civil and police operation, not a military operation. ${ }^{81}$ The British-Malayan force began achieving success when they adequately resourced their civil-military strategy, which in this context coincided with a 20:1000 troop density level.

The Malayan Emergency (1948-1960) occurred as British Commonwealth and Malayan forces fought a successful campaign against communist insurgents in the former British colony of Malaya. ${ }^{82}$ After the Japanese surrender in 1945, the Malaya Communist Party (MCP) utilized its military wing of 10,000 guerrillas in an attempt to take control of the country and fill the government void. Fortunately for the British, they had a force of 100,000 Commonwealth troops originally tasked with retaking Burma and Malaya from the Japanese, which were quickly deployed and restored the prewar colonial government structure. ${ }^{83}$

This did not end the tension, however, as the ethnic Chinese, which comprised the largest minority population (38 percent), were unassimilated into the Malayan political structure. They continued to feel disenfranchised over the perceived failure by the British to live up to their

${ }^{80}$ Thomas E. Willis II, "Lessons from the Past: Successful British Counterinsurgency Operations in Malaya 1948-1960,” Infantry Magazine, July-August 2005, http://findarticles.com/p/articles/mi_m0IAV/is_4_94/ai_n16084290 (accessed October 2, 2008).

${ }^{81}$ R. W. Komer, "The Malayan Emergency in Retrospect: Organization of a Successful Counterinsurgency Effort,” prepared for the Advanced Research Projects Agency, R-957 (Santa Monica, CA: RAND Corporation, February 1972), v, http://www.rand.org/pubs/reports/2005/R957.pdf (accessed January 2, 2009). Komer was a US Army and CIA veteran who assisted General Westmoreland in Vietnam as the first Civil Operations and Revolutionary Development Support (CORDS) director. CORDS was the US civil element in charge of South Vietnam's pacification program under MACV (Military Assistance command, Vietnam).

${ }^{82}$ McGrath, “Boots on the Ground,” 33-34.

${ }^{83}$ Ibid. 
promise of providing them full Malayan citizenship. ${ }^{84}$ In addition, the MCP was led and dominated by predominantly ethnic Chinese communists who accused the British of attempting to exclude them from power as the British were preparing Malaya for future independence. Using these grievances to gain support for an armed revolt, the MCP began a full-scale insurgency in 1948. In 1949, the MCP’s military wing changed its name to the Malayan Races’ Liberation Army (MRLA) to conjure feelings of nationalistic sentiment amongst the population. Apart from the ethnic Chinese, however, the MCP found little support for replacing the existing government with a communist one. ${ }^{85}$

Overall, the Malayan COIN campaign can be divided into three general phases. ${ }^{86}$ The initial phase (1948-50) is characterized by British underestimations of the enemy, expectations of quick success, and the lack of an integrated COIN strategy. Without a single person responsible for the overall COIN operation, police, military, and civil efforts were disjointed and uncoordinated. ${ }^{87}$ During this phase, the military’s focus was on large unit sweeps, conducted at battalion and even brigade-size. Although these sweeps destroyed numerous insurgent camps and killed the communist leader, they often lacked sufficient actionable intelligence, which allowed the enemy forces to escape while exchanging casualties almost equal in number. The large sweeps also forced the enemy to adapt and operate at small unit levels. ${ }^{88}$

During this phase, the MRLA had great success against the government security forces and against the infrastructure through a rural guerrilla insurgency. The MRLA focused their attacks on rubber plantations, tin mines, and railroads in an attempt to disrupt the government's

\footnotetext{
${ }^{84}$ Komer, “The Malayan Emergency in Retrospect,” 6; Willis, “Lessons from the Past.”

${ }^{85}$ Willis, "Lessons from the Past."

${ }^{86}$ McGrath, "Boots on the Ground," 34.

${ }^{87}$ Willis, "Lessons from the Past”; McGrath, “Boots on the Ground,” 34.

${ }^{88}$ McGrath, "Boots on the Ground,” 34-35. Komer, “The Malayan Emergency in Retrospect,” 50; Willis, "Lessons from the Past."
} 
economy, and on the police and local authorities to undermine the government's security. These attacks were occurring faster than the COIN forces could respond and therefore, could not effectively protect the local population from intimidation and control by the MRLA. ${ }^{89}$

The British immediately recognized the insurgent threat and declared an emergency two days after the first attack. The British, however, had a meager force of 21,444 combined British, Commonwealth, and Malayan security forces available for a Malayan population of almost 4.9 million. ${ }^{90}$ This produced a troop density of only 4.4 security forces per 1,000 inhabitants, which proved insufficient.

By 1950, the insurgents were gaining the upper hand and increasing their number of attacks. At this point, the British realized their strategy was failing and appointed Sir Harold Briggs, a retired Lieutenant General, to lead operations. Briggs adapted a new methodology, referred to as the "Briggs Plan." 91 This change in leadership and strategy shifted the war into the middle phase (1950-57) where the British COIN effort transformed into a systematic, coordinated, and highly effective approach. The basis of the strategy was to shift the focus of the force to providing security for the rural population while simultaneously removing the primary sources of MRLA sustainment and recruitment, the large population of Chinese squatters. ${ }^{92}$ It also shifted operations from large unit search and destroy operations to smaller, intelligencesupported operations against the MRLA organization. ${ }^{93}$ Company-size "bases” were established,

${ }^{89}$ Willis, “Lessons from the Past."

${ }^{90}$ Forces include 11,444 soldiers comprised of 11 under-strength infantry battalions: 6 Gurkha, 3 British, and 2 Malayan; along with 10,000 Malayan police for an approximate total of 21,444. Data used is from Komer, “The Malayan Emergency in Retrospect,” 38; McGrath, "Boots on the Ground,” 39-43; Thompson, Defeating Communist Insurgency, 29, 48.

${ }^{91}$ McGrath, "Boots on the Ground," 35.

${ }^{92}$ Ibid., 35-36.

${ }^{93}$ Willis, "Lessons from the Past." 
in which platoon and smaller elements would conduct patrols and ambushes, which proved more successful. $^{94}$

The final phase (1957-60) is signified by Malaya gaining its independence in 1957 and continuing COIN operations against the MRLA’s last strongholds. When Malaya gained its independence, more than 60 percent of the country was declared free of active insurgents. Only two significant areas remained under insurgent control, the Johore area, which was strongly ethnic Chinese in the south and in the north along the border with Thailand. ${ }^{95}$

For this study, the middle phase is the most significant in examining the operational environment factors that influenced the troop density the combined British-Malayan government used to achieve success. This will identify the key aspects that allowed the COIN force to be successful with the 20:1000 ratio. By 1950, the British better understood the enemy, including their motivation, goals, and strategy, which was critical for developing their civil-military COIN strategy. The MRLA pursued a Maoist strategy aimed at the independence of a communist state through the execution of a rural insurgency, utilizing the inaccessible jungle as their base. ${ }^{96}$ Being isolated from external support, including sanctuary, material, and personnel, the MRLA were completely dependent upon internal support, primarily from the Chinese squatters. ${ }^{97}$

To defeat this insurgency, the British implemented a comprehensive and coordinated COIN strategy; involving civil, police, and military actions focused on their individual strengths and the MRLA's weaknesses. Their civil-military strategy focused on breaking the links between

${ }^{94}$ Komer, “The Malayan Emergency in Retrospect,” 50.

${ }^{95}$ McGrath, “Boots on the Ground,” 37-38.

${ }^{96}$ Komer, “The Malayan Emergency in Retrospect,” 6, 80.

${ }^{97}$ Ibid., 5, 58, 78. Without significant external support, some may claim that the insurgency was unviable from the start and all the British had to do was wait the MRLA out. Clearly, this was an advantage for the British, but in a COIN environment, no one element is decisive. The country had enormous supplies of weapons and ammunition from WWII; what the insurgents most lacked was food. Despite the lack of external military support, the Malayan conflict continues to be a worthy study because of its successful civil-military strategy, specifically the civil aspects of the COIN operation. 
the insurgents and their popular base through control and accommodation-to control those people and resources that supported the MRLA, while accommodating those popular aspirations which would undermine the insurgent's political appeal. ${ }^{98}$ To control the support provided to the MRLA, the government exploited the MRLA weakness of relying exclusively on the rural population, predominantly the Chinese squatters. The “Briggs Plan” implemented several initiatives, including increased emphasis on police and intelligence capabilities to improve the security of rural villages, a food control program to create accountability for retailers and the population, strict population controls, and the Chinese squatter resettlement program. ${ }^{99}$ For accommodation, the British helped Malaya move toward enfranchising its citizens, self-government, and independence. They encouraged liberalizing citizenship laws to bring the minorities into the Malayan political fold. The British also utilized the government's advantage of having an effective administration, including rural administration, which did not break down during the insurgency. ${ }^{100}$ Relying upon a system of committees, which included local civil and military authorities, decisions were made on how to best succeed in the struggle against the insurgents, while also winning the support of the people. To this end, the central government increased the statutory authority of local governments, which empowered them to oversee the use of public funds for local improvements. The resettlement of villages was also successful due to effective administration. With excellent planning and foresight, the government provided each squatter with ownership of land, five months worth of provisions, and services within the village including water, schools, shops, medical clinics, and security. Through these efforts, the government earned the support of the squatter population and severely reduced the logistical

\footnotetext{
98 Ibid., 53.

${ }^{99}$ Willis, "Lessons from the Past."

${ }^{100}$ Komer, “The Malayan Emergency in Retrospect,” 64, 79, 84.
} 
support available to the MLRA. ${ }^{101}$ As Sir Gerald Templer, the High Commissioner (senior British official that replaced Briggs) stated, "the answer [to the terrorists] lies not in pouring more soldiers into the jungle, but rests in the hearts and minds of the Malayan people.”"102

Templer, who reinvigorated Brigg's strategy, realized he needed to further improve the security of the rural population to protect them from the influence and intimidation of the MRLA. His strategy adjustment required an increase in security forces, which he filled by calling on the Malayan population to play a role in fighting the communists. ${ }^{103}$ Through predominantly indigenous support, security forces reached their highest levels in 1952 with approximately 101,000 British, Commonwealth, and Malayan forces conducting COIN operations, which produced a troop density ratio of 20.8 security forces per 1,000 inhabitants. ${ }^{104}$ With adequate strength and a comprehensive COIN strategy, Malayan COIN forces broke the military strength of the MRLA, so by the end of 1954 their end was apparent. ${ }^{105}$

A critical feature of the COIN effort was the primary role assigned to the police, with the military having the supporting role. Not only did the Malayan police and associated forces field the majority of the COIN force, they were central to the success of the COIN effort by enforcing the rule of law and protecting the populace from insurgents. Their efforts also freed the military

\footnotetext{
${ }^{101}$ Willis, “Lessons from the Past”; Komer, “The Malayan Emergency in Retrospect,” 54-56.

${ }^{102}$ Komer, “The Malayan Emergency in Retrospect,” 54.

${ }^{103}$ Willis, "Lessons from the Past."

${ }^{104}$ Forces include 30,000 British, Commonwealth, and Malayan Army soldiers (11 British, 8
} Gurkha, 3 Commonwealth, and 7 Malayan battalions), 28,000 Malayan police, 40,000 Special Constables, and 3,000 Police Field Force for an approximate total of 101,000. Ratio is based upon an estimated 1948 population of 4.9 million. Data used is from Komer, "The Malayan Emergency in Retrospect," 38-40, 47; McGrath, "Boots on the Ground," 39-45; Thompson, Defeating Communist Insurgency, 48. The Home Guards, which numbers range from 150,000-250,000 are not included in the troop density calculation since they were a part-time, militia-type force, which does not fit within the definition of security forces as stated in FM 3-24, Counterinsurgency. If added, using an estimation of 50,000 Home Guards on duty and armed at a given time, the force ratio would jump to 30.8 per 1,000 .

105 Thompson, Defeating Communist Insurgency, 45. 
forces to focus on offensive operations. ${ }^{106}$ To assist the police and overall COIN effort, two unique police units were developed. The most critical contribution came from the Special Branch, which was the primary intelligence agency for both military and police forces. The other was the Police Field Force, which was organized into platoon-size elements and specially trained for jungle patrols. They conducted approximately one third of all jungles patrols and ambushes conducted by the COIN force. ${ }^{107}$

With Templer's focus on increasing security of the rural populations, he also provided a new impetus for two under-resourced, yet vital organizations. These were the Special Constables and the Home Guards. The Special Constables, which numbered up to 44,000, were used to guard vital installations, plantations, and mines. This force became vital when the relocation of Chinese squatters forced the insurgents to look for supplies at the mines and plantations. ${ }^{108}$ In addition, as security and their training improved, they were organized into area security units and became a major enabler for the government’s food enforcement. ${ }^{109}$ The Home Guards, conservatively numbered at 150,000, were built upon an existing initiative of part-time village guards for protection. The British formalized the program and, under police oversight, increased their numbers, training, and arms. The organization was then used to secure the new Chinese villages created from squatter resettlement and, as a political means, involved the Chinese in the government effort and the protection of their own homes. By 1955, the Home Guard was fully responsible for securing 170 of 410 Chinese villages, along with villages of other ethnicities. ${ }^{110}$ In analyzing other aspects of the operational environment that influenced force levels, the most significant and directly related was the geography of Malaya. Malaya is a small country,

\footnotetext{
${ }^{106}$ Komer, “The Malayan Emergency in Retrospect,” v, 38.

107 Ibid., 39-44.

108 McGrath, "Boots on the Ground,” 45.

${ }^{109}$ Komer, “The Malayan Emergency in Retrospect,” 40.

${ }^{110}$ Ibid., 40-41.
} 
roughly the size of Alabama, and located on a peninsula having a ground border only with Thailand, made Malaya easy to isolate. ${ }^{111}$ Being a small, easy to isolate country with a small population dramatically assisted the COIN forces with denying the insurgents external support.

The next most significant factor was the cultural aspects of the insurgency. The popular base of the MRLA was almost entirely limited to the ethnic Chinese minority (1.9 million) and never spread to the Malayan majority (2.4 million) or other ethnic groups. ${ }^{112}$ This large Chinese population contained about 500,000 squatters that farmed on the edge of the jungle. The squatters almost exclusively provided the insurgents with subsistence and recruits. ${ }^{113}$ Clearly, the cultural composition of the MRLA and their single source of support made it easier for the COIN forces to focus their efforts and internally isolate the insurgents from the population through squatter resettlement, increased security for the rural population, and civil programs. ${ }^{114}$

Also significant were the political influences. The British-Malayan government recognized the insurgent's main political cause and strove to undermine it. As the MRLA called for violent revolution as the only way to achieve independence, the British-Malayan government continued its steady move toward Malayan independence and liberalized citizenship laws to bring minorities into the political fold. ${ }^{115}$ Therefore, the insurgents were unable to establish widespread popular support, even within the ethnic Chinese. The British also had the advantage of a long and solid relationship with local Malayan rulers. Their understanding of Malayan culture and local governance enabled the British to provide effective leadership during the conflict. ${ }^{116}$

${ }^{111}$ McGrath, "Boots on the Ground,” 39.

${ }^{112}$ Komer, “The Malayan Emergency in Retrospect,” 78.

${ }^{113}$ McGrath, "Boots on the Ground,” 39.

${ }^{114}$ Komer, “The Malayan Emergency in Retrospect” 53. Examples of civil programs include registration and travel control, identification card checks, curfews, food control programs, social and economic development, citizenship law reform, and the move to self-governance and independence.

\footnotetext{
${ }^{115}$ Ibid., v, 64.

${ }^{116}$ Ibid., 79, 82, 84, 87.
} 


\section{Iraq Case Study}

The Iraq War is an important case study to include since it is the most recent US COIN effort, involves large number of US forces operating under the new modular force structure, and incorporates the latest doctrine and technological advances. ${ }^{117}$ Although Iraq is not fully selfsecuring at the time of this writing, the security environment has improved to the extent that Iraqi life is returning to normal and COIN operations appear to be on the path to success. ${ }^{118}$ This assertion of expected success is supported by several factors. First, the central government is demonstrating its growing maturity and desire to exert its sovereignty by passing a Status of Forces Agreement (SOFA) in setting a timeline for US withdrawal. ${ }^{119}$ Second, ISF have taken the lead in several major military operations, and have the security responsibility for the majority of Iraqi provinces. ${ }^{120}$ Finally, stability and normalcy have returned as the lack of essential services, rather than security, is the most important concern upon the minds of most Iraqis. ${ }^{121}$ This success,

${ }^{117}$ Modular BCTs began operations in Iraq in 2005 with the $3^{\text {rd }}$ Infantry Division and $101^{\text {st }}$ Air Assault Division. Andrew Feickert, “U.S. Army’s Modular Redesign: Issues for Congress,” Congressional Research Service Report for Congress (May 5, 2006), 21, http://fpc.state.gov/documents/organization/67816.pdf (accessed January 29, 2009). For modular BCT structures, see Appendix D and E.

${ }^{118}$ US Department of Defense, “Measuring Stability and Security in Iraq,” Quarterly Report, Report to Congress in Accordance with the Department of Defense Appropriations Act of 2006-2008 (December 2008), 18, http://www.defenselink.mil/home/features/Iraq_Reports/ (accessed January 13, 2009).

${ }^{119}$ The SOFA approved by the Iraqi Parliament calls for US forces to withdrawal from Iraqi urban areas by July 2009, and a full withdrawal from Iraq by December 31, 2011, with certain exceptions and caveats. Greg Bruno, "U.S. Security Agreements and Iraq,” Council on Foreign Relations, November 18, 2008, http://www.washingtonpost.com/wp-dyn/content/article/2008/11/18/AR2008111801118.html (accessed December 20, 2008); US Department of Defense, "Measuring Stability and Security in Iraq," Quarterly Report December 2008, iii.

${ }^{120}$ Thirteen of Iraq’s 18 provinces have been transferred to Iraqi control as of November 2008. Major operations include Basra, Diyala, and Sadar City. Aseel Kami, "Iraq Takes over Guard Programme in Restive Province," Reuters, January 4, 2009, http://www.reuters.com/article/latestCrisis/idUSL4641298 (accessed on January 13, 2009); US Department of Defense, "Measuring Stability and Security in Iraq," Quarterly Report December 2008, iv.

${ }^{121}$ US Department of Defense, "Measuring Stability and Security in Iraq," Quarterly Report December 2008, vi, 18. Normalcy is relative, but in this situation, it supports the point that violence has returned to pre-war levels as indicated by General Petraeus. Phil Stewart, "Iraq Violence at 5-1/2 Year Low 
coincidently, became apparent only after a comprehensive COIN-focused strategy was

implemented, along with the necessary force levels needed to execute it, which approached the 20:1000 ratio.

The Iraq campaign, called Operation IRAQI FREEDOM (OIF), is the second major USled combat operation directed toward Iraq. ${ }^{122}$ The strategic aim was to remove Saddam Hussein and the Baathist party from power to eliminate Iraq's ability to threaten the US and its allies. The claim was that Saddam possessed weapons of mass destruction (WMD), which he intended to use against the US and its allies either directly himself or indirectly through terror organizations such as al-Qaeda. ${ }^{123}$ By removing the repressive Baath party, the Coalition could build a stable country with a representative government that would be able to prevent its territory from being used as a base for terrorism and regional aggression, as well as provide another ally in the Middle East. ${ }^{124}$

In March 2003, the US-led Coalition quickly overwhelmed and defeated Iraq’s military, seized Baghdad, toppled the Baathist regime, and occupied Iraq. The invasion force, conducting a swift and stunning conventional warfare operation, ended Saddam’s 30-year reign over Iraq by early April 2003. ${ }^{125}$ Yet, as the invasion force pushed toward Baghdad, Saddam’s loyal paramilitary organizations, including Fedayeen Saddam, directed attacks against the Coalition's

Petraeus Says,” Reuters, December 9, 2008, http://www.newsdaily.com/stories/tre4b86g7-us-iraq-petraeus/ (accessed December 20, 2008).

${ }^{122}$ Wright and Reese, On Point II, 9-12. The US-led conflict with Iraq has been ongoing and intensifying since the end of the Gulf War in 1991. In January 1991, the US and a large coalition took direct military action against Iraq after Saddam Hussein's invasion of Kuwait in August 1990. Upon the conclusion of the campaign, Saddam's military was gravely weakened. However, they still posed a threat internally as Saddam used his military to brutally suppress internal uprisings that threatened his regime. To prevent further repression by the Iraqi Army, the US created and patrolled the northern and southern no-fly zones. The US also took action against Iraqi's WMD production through a three-day offensive known as DESERT FOX and worked through the UN to implement a policy of isolation using trade sanctions and weapons inspections. Furthermore, the US passed the Iraqi Liberation Act of 1998, which made it official US policy to depose of Saddam.

$$
\begin{aligned}
& { }^{123} \text { Ibid., 14-15. } \\
& { }^{124} \text { Ibid., 46. } \\
& { }^{125} \text { Ibid., 9, 15, } 19 .
\end{aligned}
$$


lines of communications (LOCs). These paramilitary units responded in the manner they were created for-to suppress internal insurrection or other opposition that threatened regime power. ${ }^{126}$ This resistance was the first sign that not all Iraqis would warmly welcome the Coalition. It also led Lieutenant General Wallace, the V Corps Commander, to comment to The New York Times, “The enemy we're fighting is a bit different than the one we war-gamed against, because of these paramilitary forces." 127

After the Coalition's overwhelming success against the Iraqi military and the quick fall of the Baathist regime in Baghdad, the Coalition then began the transition from primarily offensive operations to stability operations. During that transition, Iraq's institutions that were held in control by Saddam's heavy hand began to collapse. Some Iraqis began to sense a vacuum in the security situation and long-suppressed political, religious, and ethnic conflicts began to renew, along with massive civil disorder. ${ }^{128}$

The Iraq COIN campaign can be divided into three phases. The initial phase (May 2003January 2006) is signified by the establishment of the Coalition Provisional Authority (CPA) that administered the occupation of Iraq, and the Iraqi general elections of 2005. This phase was a chaotic period for the Coalition, with little strategic coordination and a growing insurgency. ${ }^{129}$

${ }^{126}$ Ibid., 15, 103.

${ }^{127}$ Jim Dwyer, “A Nation at War: In the Field-V Corps Commander; A Gulf Commander Sees a Longer Road,” New York Times, March 28, 2003, http://query.nytimes.com/gst/fullpage.html?res=9C01E4D81F30F93BA15750C0A9659C8B63\&sec=\&spo n=\&pagewanted=2 (accessed February 13, 2009).

${ }^{128}$ Wright and Reese, On Point II, 19, 25.

${ }^{129}$ Thomas Donnelly and Frederick W. Kagan, Ground Truth: The Future of U.S. Land Power (Washington D.C.: The AEI Press, 2008), 59. Chaos is used to describe the difficulty that happens during transitions, which this period experienced many. Examples include the transition from combat operations to COIN and stability operations; the rapid transition of senior personnel, both civilian and military; transition of units; the campaign transitions; and the Army's transition to the modular force. Example of the lack of strategic coordination was seen with the CPA's policies. Though described in more detail later, two significant policies issued by the CPA surprised many senior military leaders and government officials, including the Secretary of State. These policies crippled many of the initiatives the military was working. Gordon and Trainor, COBRA II, 479, 483-484; Wright and Reese, On Point II, chap. 14. 
After the fall of Saddam, identity politics surfaced again as most individuals were viewed through the ethno-sectarian prism that delineated them as Shia Arabs, Sunni Arabs, or Kurds. ${ }^{130}$ The Sunni Arabs, disenfranchised after losing political power and employment through deBaathification policies, initially supported an insurgency mainly composed of ex-Baathists and Saddam's paramilitary to regain the political power and influence they held during Saddam's reign. ${ }^{131}$ To increase their popular support, the Sunnis also proclaimed they were fighting a religious war against the infidel invaders whose aim was to destroy their culture and values of Islam. In addition, anti-Coalition sentiment soon spread to other factions, including Sunni Arab rejectionists, Islamic extremists, Shia militants, Foreign Islamic extremists, and criminals due to the lack of security and restoration of essential services, the presence of foreign occupiers, and a desire for increased political power. ${ }^{132}$ Through asymmetric warfare and guerrilla tactics, the insurgents strove to make the occupation economically and politically untenable by weakening the Coalitions’ resolve, thus bringing their withdrawal. ${ }^{133}$

The Coalition first recognized the insurgency as a significant threat in the fall of 2003. In August, insurgents conducted two spectacular attacks, which signaled to the Coalition that the insurgents could coordinate attacks to achieve the strategic effect of fracturing the Coalition as

${ }^{130}$ Farook Ahmed, “Sons of Iraq and Awakening Forces,” February 21, 2008, Institute for the Study of Wars, Backgrounder no. 23, http://www.understandingwar.org/files/reports/Backgrounder\%2023\%20Sons\%20of\%20Iraq\%20and\%20A wakening\%20Forces.pdf (accessed January 13, 2009), 1.

${ }^{131}$ Wright and Reese, On Point II, 26, 99-100, 106. The CPA, headed by Ambassador Paul Bremer, made two major decisions in May of 2003 that affected Iraqis and the Coaltion. These were the "De-Baathification of Iraqi Society," and the "Dissolution of Entities." The first policy removed from public life Iraqis that held the top four ranks in the Baath Party. The second policy disbanded all of Saddam's military and intelligence institutions. Both policies rendered hundreds of thousands of Iraqi's, mostly Sunni, jobless. Because of these policies, and large offensive operations in Sunni cities (Fallujah and Samarra) Sunnis believed de-Baathification was also de-Sunnification, a belief that that every Sunni was viewed as a terrorist and they would be excluded from political power in the new Iraq.

${ }^{132}$ Ibid., 100-110.

${ }^{133}$ Wright and Reese, On Point II, 111; US Department of Defense, “Measuring Stability and Security in Iraq,” Quarterly Report March 2007, 16. 
well as the Iraqi Governing Counsel. ${ }^{134}$ As the emergent insurgency was dramatically increasing its attacks on Coalition forces, CENTCOM, however, was redeploying forces. ${ }^{135}$ At the completion of major combat operations in May, the Coalition force was approximately 168,500, but by December 2003, troop strength reduced to $145,000 .{ }^{136}$ With an estimated Iraqi population of 25.5 million in 2003, this provided a troop density of only 5.7 security forces per thousand inhabitants. ${ }^{137}$ With the low force levels, Coalition forces were unable provide security across Iraq, and likewise unable to derail the rising insurgency during its formative period. As the insurgency grew, as well as the need for increased security, the force levels did not rise to meet these conditions. ${ }^{138}$

Lieutenant General Ricardo Sanchez, the commander of Coalition forces in June 2003, believing that the regime was not fully dismantled yet, set a new campaign plan that focused on conducting FSO in order to defeat the insurgents and gain the support of the population. ${ }^{139}$ The plan’s mission statement was, “Conduct offensive operations to defeat remaining noncompliant forces...concurrently conduct stability operations to support the establishment of government and

${ }^{134}$ Wright and Reese, On Point II, 32-33. Spectacular attacks became a term used in Iraq that designated a large, casualty producing attack.

135 Ibid., 27, 29, 35-36, fig. 29. Attacks doubled from 500 per month in July to a 1000 per month in November.

136 Ibid., 170.

${ }^{137}$ McGrath, “Boots on the Ground,” 120.

${ }^{138}$ Wright and Reese, On Point II, 171. During this phase, the Coalition strength continued to fluctuate randomly, without any real pattern of force buildup or drawdown. The lowest Coalition strength total was in February 2004, with 139,000 and an unknown number of trained ISF. This provided the lowest force ratio of 5.5. The highest strength was in November and December of 2005, with 183,000 Coalition, and approximately 54,000 ISF operational and in the lead. This provided the highest force ratio at 9.3. However, the number of security incidents steadily increased from January of 2004 to July of 2007. Data is from O’Hanlon, “Iraq Index,” January 2008, 25, 33; US Department of Defense, "Measuring Stability and Security in Iraq,” Quarterly Report October 2005, 32 and December 2008, 18. The numbers of ISF present, trained, equipped, and operational, along with overall effectiveness is open to interpretation.

${ }^{139}$ Wright and Reese, On Point II, 161-163. 
economic development...”" ${ }^{140}$ With this focus, it is clear the Coalition leaders strove to win the support of the people, but they did not focus on nor have the ability to secure the population.

The middle phase (February 2006-August 2008) was signified by the eruption of civil unrest between Shia and Sunni factions after the al-Askari Mosque bombing in Samarra in February 2006, and President Bush’s new strategy. ${ }^{141}$ The al-Askari Mosque, also known as the Golden Mosque, is one of the holiest Shia shrines. With Sunni supported al-Qaeda in Iraq (AQI) held responsible for its destruction, Shia militias and death squads retaliated, spearheading a massive escalation in sectarian violence. ${ }^{142}$

Witnessing the dramatic increase in violence during 2006, President Bush realized that the deeply entrenched insurgency and vicious cycle of sectarian violence jeopardized any chance Iraq had at becoming a stable country unless decisively averted. To this end, President Bush outlined a new strategy in January 2007 that established the goals of decreasing sectarian violence, providing stability to allow government reforms and improvements to take place, and preventing Iraq from failing and becoming a safe-haven for terrorists. ${ }^{143}$ Through the strategy's implementation, significant security improvements were made as demonstrated by security

${ }^{140}$ Ibid., 163.

${ }^{141}$ US Department of Defense, "Measuring Stability and Security in Iraq,” Quarterly Report March 2007, 15. Term "civil war" has been used to describe the violence and unrest that occurred after the mosque bombing. Depending on perspective, some elements of the situation in Iraq could have been described as such, including the ethno-sectarian violence, but much of the violence was more complex with extensive Shia-on-Shia violence, al-Qaida and Sunni insurgent attacks on Coalition forces, and widespread criminality. In addition, much of the violence was focused on local issues, such as sectarian, political, and economic control of Baghdad; Kurdish, Arab, and Turkomen aspirations for Kirkuk; and the political and economic control of Shi'a regions in the south.

142 “Iraq Blast Damages Shia Shrine,” BBC News, Middle East (February 22, 2006), http://news.bbc.co.uk/2/hi/middle_east/4738472.stm (accessed January 21, 2009); Bush, "President’s Address to the Nation.” Iraq.”

${ }^{143}$ Bush, “President’s Address to the Nation”; Phillips, “President Bush’s New Way Forward in 
incidents falling to summer of 2005 levels by end of 2007 (over 60 percent drop from peak incidents in June 2007) and to summer of 2003 levels by the end of 2008. ${ }^{144}$

The last phase (September 2008-present) is signified by the withdrawal of the "surge" forces, and a true transition to Iraqi sovereignty with the implementation of the Security Framework Agreement (SFA). In addition, the ISF gained security responsibility for the majority of Iraqi provinces, with anticipated hand-over of all provinces in 2009. ${ }^{145}$ Because of the improved security environment, this phase continued a gradual Coalition troop reduction as an increasingly capable ISF expanded, aided by the Sons of Iraq. ${ }^{146}$ With the strength of the insurgency declining and normal life returning, the COIN forces have shifted focus to governance and capacity building in the majority of the country. ${ }^{147}$

For this study, the middle phase is the most significant in examining the operational environment factors that influenced the troop density used to achieve success. The most significant factor was the strategy set by President Bush. By the end of 2006, the escalating violence had become so intolerable, especially within Baghdad, that President Bush decided a new strategy was required. ${ }^{148}$ The reasons for the degraded security environment were identified as insufficient forces to hold cleared areas and excessive Iraqi political interference that restricted military operations. Therefore, to regain the initiative and establish security, the New Way

\footnotetext{
${ }^{144}$ US Department of Defense, “Measuring Stability and Security in Iraq,” Quarterly Report December 2007, 16; Stewart, "Iraq Violence at 5-1/2 Year Low Petraeus Says.”

${ }^{145}$ US Department of Defense, “Measuring Stability and Security in Iraq,” Quarterly Report September 2008, iii and December 2008, 29; Kami, "Iraq Takes over Guard Programme in Restive Province.” The “surge” units were withdrawn without replacement by September 2008.

146 The emergence of SoI is described later. The SoI are HN tribal guard units that have been leveraged to support the Coalition and GoI in fighting AQI.

${ }^{147}$ US Department of Defense, “Measuring Stability and Security in Iraq,” Quarterly Report December 2008, iii-iv, 18.

${ }^{148}$ August through October 2006 alone saw a 22 percent increase in violence, along with increased infrastructure attacks. Fifty-four percent of violence occurred in two provinces, Baghdad and Anbar. US Department of Defense, “Measuring Stability and Security in Iraq,” Quarterly Report November 2006, 1, 3; Bush, "President's Address to the Nation."
} 
Forward strategy corrected these deficiencies with increased forces, both Iraqi and US, and a promise of less Iraqi political interference. ${ }^{149}$ The strategy also outlined a comprehensive, civilmilitary approach to restore the confidence of the Iraqi people in their government. Politically, the strategy focused on undermining insurgent support through political reconciliation, passing oil revenue sharing legislation, de-Baathification reform, and increased infrastructure projects to create more jobs. To assist with local governance and economic development, the number of Provincial Reconstruction Teams was also expanded. ${ }^{150}$

Militarily, the strategy focused on the acceleration of ISF training and partnering with them to clear and hold neighborhoods to protect the population. This required the COIN force to adapt a more permanent presence in the towns through establishing Joint Security Stations and combat outposts. ${ }^{151}$ This change also restored the tactical level COIN imperative of maintaining presence with the people as opposed to what has been referred to as "commuting to work" from large forward operating bases (FOBs). ${ }^{152}$ Learned again through experience, presence is a precondition for success. ${ }^{153}$ As David Galula wrote in his 1964 classic Counterinsurgency Warfare: Theory and Practice:

It seems natural that the counterinsurgent's forces should be organized into two types of units...the static ones staying with the population in order to protect it and to supplement the political efforts. The static units are obviously those that know best the local situation, the population, the local problems;... ${ }^{154}$

${ }^{149}$ Bush, "President's Address to the Nation."

${ }^{150}$ Bush, "President's Address to the Nation”; US Department of Defense, "Measuring Stability and Security in Iraq,” Quarterly Report March 2007, 1, 15.

${ }^{151}$ Bush, “President’s Address to the Nation”; US Department of Defense, “Measuring Stability and Security in Iraq,” Quarterly Report March 2007, 15.

152 US Army FM 3-24, Counterinsurgency, 5-20; Donnelly and Kagan, Ground Truth, 105; Wright and Reese, On Point II, 584.

153 Donnelly and Kagan, Ground Truth, 90.

${ }^{154}$ David Galula, Counterinsurgency Warfare: Theory and Practice (1964; repr., St. Petersburg, FL: Hailer Publishing, 2005), 93. Galula's book is a classic since it is as relevant today as when it was published decades ago. This work provides a thorough and sound analysis of the COIN environment. 
To implement the strategy, the Iraq command team of Ambassador Ryan Crocker and General David Petraeus developed a Joint Campaign Plan, which translated the President's strategy into operational objectives and priorities. ${ }^{155}$ To rebalance the resources needed to achieve these objectives, the US increased its force levels by deploying the "surge" forces, along with intensifying the effort to increase the size and effectiveness of the ISF. By the summer of 2007, the surge force deployment was complete and raised the Coalition strength to its highest "surge" level of $182,668{ }^{156}$ The ISF also grew to 278,198 operational security forces, adding over 100,000 trained-forces in $2007 .{ }^{157}$ With an Iraq population estimated at 27.5 million, the COIN forces fielded 460,866 security forces for a troop density ratio of 16.8 per thousand population. ${ }^{158}$ Coincidently, by the end of 2007, violent attacks had dramatically declined and the conditions for sustainable stability were being established. ${ }^{159}$

${ }^{155}$ Lieutenant General James Dubik Ret., “No Holy Grails, No Silver Bullets,” Army, February 2009, 18-20. Priorities included focusing the security effort on Baghdad and Anbar Province. Baghdad and surrounding areas were critical due to the high level of sectarian violence, and with Baghdad being the capital city; it set the example for the rest of Iraq. Anbar was also critical, as it became an insurgent stronghold and Iraq's most violent province. US Department of Defense, "Measuring Stability and Security in Iraq,” Quarterly Report March 2007, 15 and December 2007, 22.

${ }^{156}$ O’Hanlon, “Iraq Index,” January 2008, 25; US Department of Defense, “Measuring Stability and Security in Iraq," Quarterly Report September 2007, iii. This level was reached in October 2008.

${ }^{157}$ US Department of Defense, "Measuring Stability and Security in Iraq," Quarterly Report December 2007, 29, 39, 42, 46. Iraqi security force of 278,198 is calculated based upon November 2007 data. For the Iraqi military, only Army data is used since it is the predominate force involved in COIN operations. Of the Iraqi Army's operational divisions, it had approximately 137,000 assigned soldiers and officers at a $79 \%$ present for duty strength, which calculates to 108,230 soldiers. The National Police had 32,517 assigned members at $60 \%$ present for duty strength for a total of 19,510 . The police at 255,600 assigned and the Border Enforcement at 38,751 assigned both have approximately 50\% present for duty strength, for totals of 127,800 and 19,375. Finally, the counter-terrorism units have 3,283 members.

Although care was taken to only use operational-unit data, there is still a high degree of uncertainty with ISF data, including numbers present, trained and equipped. This is according to the Office of the Special Inspector General for Iraq Reconstruction in the article: William McMichael, "IG: Dead Count Toward Iraqi Force Strength,” ArmyTimes, April 28, 2008,

http://www.armytimes.com/news/2008/04/military_isfreport_042508/ (accessed January 21, 2009).

${ }^{158}$ US Department of State, July 2007 Iraq population estimate, under Background Notes/Iraq, http://www.state.gov/r/pa/ei/bgn/6804.htm (accessed February 15, 2009).

${ }^{159}$ US Department of Defense, “Measuring Stability and Security in Iraq,” Quarterly Report December 2007, 16. 
To assist with the security environment, Coalition leaders and the Government of Iraq (GoI) shifted the paradigm during this phase to leverage Iraq’s long-standing tribal structures. Coalition leaders saw an opportunity to exploit a rift that was occurring between the Sunni tribal leaders and AQI in Anbar. As the tribal leaders and the population were becoming alienated with AQI’s draconian measures and intimidation, Coalition leadership supported their tribal awakening movement. Despite the tribal leaders’ resentment towards Iraq’s new central government and Coalition forces, they withdrew their passive and sometimes active support for AQI and became active supporters of the COIN effort. ${ }^{160}$ Formed into tribal guard units, known as the Awakening and later as the Sons of Iraq (SoI), they took up the fight against AQI, to which Coalition leaders repeatedly credit for a large portion of the stability effort, especially in Baghdad and Anbar. ${ }^{161}$

Since the Awakening and the new strategy implementation took place near simultaneously, it is difficult to determine the effect of either one alone, but the combined effect on Iraq’s security situation in late 2007 through 2008 is indisputable. Although not included in the troop density ratio, the SoI were clearly a critical component of the COIN force's success due to their understanding of the local populace and culture, their willingness to secure local neighborhoods and infrastructure, and their ability to identify suspected insurgents. ${ }^{162}$ With the

${ }^{160}$ Ahmed, “Sons of Iraq and Awakening Forces,” 1.

${ }^{161}$ Kami, “Iraq Takes over Guard Programme in Restive Province”; Ahmed, "Sons of Iraq and Awakening Forces,” 2, 4, 7. For example, Baghdad witnessed a decline in ethno-sectarian deaths from a high of over 1,600 in December 2006 to 11 in May 2008; US Department of Defense, "Measuring Stability and Security in Iraq,” Quarterly Report June 2008, 27. Same is found in Anbar, which had the highest number of attacks of any province in August 2006 with over 30 a day, reduced to five a day in June 2008. US Department of Defense, “Measuring Stability and Security in Iraq,” Quarterly Report June 2008, 28 and August 2006, 32.

162 Including the 70,000 SoI, the total security force level in Iraq increases to 530,866 at the end of 2007, which produces a troop density ratio of 19.3. Data from US Department of Defense, "Measuring Stability and Security in Iraq,” Quarterly Report December 2007, 30 and March 2008, 17. SoI as a group are not considered part of the ISF, although some are being incorporated into the ISF, primarily the police. Therefore, they are classified as militia-type forces and fall outside the security force definition as defined by FM 3-24, and are not included in the force ratio calculation. 
emergence of the SoI, in conjunction with the force increases and COIN-focused strategy, the necessary security conditions were set to achieve the tipping point where the path to improved security and normalcy was established.

In examining other aspects of the operational environment that influenced force levels in Iraq, a significant challenge was understanding the nature of the conflict with its multiplicity of groups and goals. This multiplicity included both internal and external actors. Internal actors became associated with identity politics that surfaced after the removal of Saddam's heavy hand. Without sufficient security, violence increased as these groups battled to gain political power and to settle sectarian scores, as well as to undermine the central government and encourage the withdrawal of Coalition forces. ${ }^{163}$ External actors included al-Qaeda, Iranian elements, and foreign fighters who fought for religious and political causes. They focused on expelling Western occupiers of an Islamic country and increasing their influence. In the case of AQI, an additional goal included beginning a civil war between the Shia and Sunnis, which would bring the demise of Iraq's fledgling government and clear the way for its global caliphate. ${ }^{164}$ To precipitate this withdrawal, the insurgents employed information operations using mass media to shape public perceptions abroad and at home. Both audiences were targeted with images of insurgent attacks and Coalition setbacks to undermine support for the war abroad and to inspire support for the insurgents at home and within the Arab region. ${ }^{165}$

Iraq's geography was also instrumental in facilitating the growth of opposition groups, and thus significantly influenced force levels. Iraq is a large country about the size of California,

163 US Department of Defense, “Measuring Stability and Security in Iraq,” Quarterly Report March 2007, 16.

${ }^{164}$ Bard E. O’Neill, Insurgency and Terrorism: From Revolution to Apocalypse, $2^{\text {nd }}$ ed. (Dulles, VA: Potomac Books, Inc., 2005), 11, 65-66; US Department of Defense, "Measuring Stability and Security in Iraq,” Quarterly Report June 2008, 7; Wright and Reese, On Point II, 110.

165 James Russell, “Strategic Implications of the Iraq Insurgency,” Middle East Review of International Affairs 8, no. 2 (June 2004), http://www.ccc.nps.navy.mil/people/biolinks/russell/russell\%20\%20insurgency.pdf (accessed January 13, 2009), 49. 
and is almost entirely landlocked with long porous borders. Iraq has two neighbors, Syria and Iran that actively support destabilizing activities in Iraq. These countries, along with organizations like al-Qaeda, provide political, ideological, material, foreign fighters, and financial support to these destabilizing efforts. ${ }^{166}$ Due to Iraq’s size and antagonistic neighbors, the small COIN force could not isolate the insurgents from receiving external support. ${ }^{167}$ Iraq's geography also facilitated internal support for the insurgents. In preparing for a military confrontation with the US and for internal opposition, Saddam's government turned Iraq into a large ammunition supply depot. Left mostly unguarded due to limited forces, vast resources were available for insurgent use. ${ }^{168}$ In addition, Iraq is a highly urbanized state, with over three-quarters of the population being city dwellers. This is significant as a concentrated population made it easier for insurgents to control the population, garner support, and hide their activities. Urban areas also increase the difficulty for COIN forces, as they are a great equalizer of many technological advantages. ${ }^{169}$

Another factor that affected force levels was the lack of HN security forces. The Iraq Army, in particular, was a major source of manpower that CENTCOM planners counted on to bolster their security forces in support of their occupation efforts. ${ }^{170}$ However, Iraqi units "selfdemobilized” shortly after the fall of Baghdad and only one, without soldiers, surrendered to 2007, 6, 7.

${ }^{166}$ US Department of Defense, “Measuring Stability and Security in Iraq,” Quarterly Report June

${ }^{167}$ Gordon and Trainor, COBRA II, 4.

${ }^{168}$ Ricks, Fiasco, 191; Gordon and Trainor, COBRA II, 122, 136.

${ }^{169}$ Gordon and Trainor, COBRA II, 104. Cities tend to mitigate the technological advantages of ISR, fire support, and aviation due to their dense populations, within which the insurgents can hide, mass and disperse, their physical barriers such as buildings and underground infrastructure, and political sensitivities of civilian casualties and collateral damage. US Joint Forces Command, "The Joint Operating Environment 2008: Challenges and Implications for the Future Joint Force,” Center for Joint Futures (J59) (November 25, 2008), https://us.jfcom.mil/sites/J5/j59/default.aspx (accessed March 6, 2009), 40, 47.

${ }^{170}$ Ibid., 105, 145, 153. CENTCOM envisioned using the Iraqi Army for security, while Jay Garner, who led the Office of Reconstruction and Humanitarian Assistance (ORHA), which would oversee postwar nation-building activities, planned to use them as a source of labor. 
Coalition forces. ${ }^{171}$ Iraqi police also abandoned their posts and had to be reconstituted. ${ }^{172}$ Even as new Iraqi military units were being formed, challenges remained in getting them operational. The police and army required significant institutional and organizational reforms, equipment, and training in order for them to be used and trusted as peace enforcers rather than aggressors. Corruption, insurgent infiltration, and sectarian interests detracted from their effectiveness and had to be mitigated. ${ }^{173}$

Other significant factors that influenced force levels were the directed mission and the Coalition's lack of understanding of the cultural environment. Clearly, with a directed mission of regime change, the operation increased in complexity as rebuilding governance from local to national level competed with other COIN tasks. ${ }^{174}$ In addition, to get Iraqi assistance and "buyin” towards accomplishing any of the COIN objectives, Coalition leaders had to build relationships with Iraqis across a wide culture barrier. As General Abizaid stated, "We are an antibody in their society." 175 Therefore, it was critical to present Iraqis as in charge of both governance and security efforts to avoid the taint that accompanies occupier status. However, the decisions made by the CPA, including de-Baathification, disbandment of the Iraqi Army, and delaying the turnover of power to the Iraqi Government, did exactly that. ${ }^{176}$ Although senior leaders recognized the importance of placing an Iraqi face on operations, an adequate level of cultural understanding did not exist. Efforts were lacking in the areas of history, religion, culture,

\footnotetext{
${ }^{171}$ Ibid., 462, 480.

${ }^{172}$ Ibid., 465.

${ }^{173}$ Wright and Reese, On Point II, 428-429; Gordon and Trainor, COBRA II, 466; Joseph A.
} Christoff, "Rebuilding Iraq: Preliminary Observations on Challenges in Transferring Security Responsibilities to Iraqi Military and Police,” United States Government Accountability Office Testimony (March 14, 2005), http://www.gao.gov/new.items/d05431t.pdf (accessed January 26, 2009), 12-15.

\footnotetext{
${ }^{174}$ Wright and Reese, On Point II, 118.

${ }^{175}$ Gordon and Trainor, COBRA II, 163.

${ }^{176}$ Wright and Reese, On Point II, 31; Gordon and Trainor, COBRA II, 314, 475, 479, 480, 495.
} 
traditions, and language, which prevented the Coalition's ability to map the human terrain and fully appreciate the internal struggles and perspectives of the population. ${ }^{177}$

Finally, the concept of time also influenced the security environment. With the Iraqi military collapsing so quickly and the majority of the country being an "economy of force" due to the limited Coalition presence, significant portions of the country had not seen Coalition forces or realized their own forces were defeated. ${ }^{178}$ The Coalition was also clearly unprepared for the quick collapse of Iraqi security institutions, and missed re-establishing security and the rule of law within the "golden hour" after the fall of Saddam. ${ }^{179}$ A COIN environment developing after major combat operations or at the beginning of a failed state is not predetermined if adequate planning and resourcing are brought forth quickly to reestablish security. This effort can avert chaos and prevent criminal and insurgent organizations from gaining a foothold in society. In Iraq, however, this did not occur. Combined with a political and security vacuum, a disenfranchised population with available ordnance, and a religious ideological cause, the conditions were set for an insurgency to form. Time would be required for the people grow tired of the violence and desire peace.

Another aspect of time is duration. Insurgencies are protracted by nature, which necessitates considerable time and resources on the part of the COIN force to pacify the population and achieve results. For example, Malaya took 12 years while Iraq is currently in its sixth year. Therefore, COIN requires an enduring effort in both policy and resources. The time

\footnotetext{
${ }^{177}$ Wright and Reese, On Point II, 585; Julian D. Alford and Scott A. Cuomo, "Operational Design for ISAF in Afghanistan: A Primer,” Joint Forces Quarterly 53 (2 ${ }^{\text {nd }}$ Quarter 2009), 94.

${ }^{178}$ Gordon and Trainor, COBRA II, 459, 462.

${ }^{179}$ Ibid., 467. The term golden hour refers to the critical hour following a life trauma when medical intervention, or the lack of, determines the fate of the victim. It is used here in the same meaning. There is a finite window of time (weeks) to reestablish security and the rule of law after major combat operations, during which external intervention may enjoy some popular support and international legitimacy, and during which the opposition will be off-balance. Jones, "Establishing Law and Order After Conflict,” xi-xiii, 208.
} 
needed to produce results; to restore essential services, defeat insurgents, improve governance and economic conditions, and build HN security forces, is often at conflict with expectations. Especially in Iraq, the US-led Coalition had to overcome the population's “man on the moon syndrome," where disbelief was expressed in the time it took these improvements to be made from a nation that had a reputation for grand accomplishments. ${ }^{180}$

\section{Section 3-Analysis}

\section{Troop Density Ratio Synthesis:}

In analyzing the quantitative factors of the case studies of Malaya and Iraq, it is clear the 20:1000 ratio is still a valid planning gauge, even for today’s technologically advanced units. As the studies have shown, the chances of reaching the tipping point for success increases as one's force level nears the 20:1000 ratio when confronting an insurgency. To tip the scale in favor of the COIN force, Malaya required a ratio of 20.8 and Iraq a ratio 16.8 (19.6 including SoI). This is not a surprise, since a key principle in COIN operations is to secure the population and that requires "boots on the ground."

However, this planning gauge is not absolute, since force levels are dependent upon the context of the strategic setting and the operational environment of each specific situation.

Therefore, when the qualitative factors of the case studies are analyzed, dramatic differences affecting troop levels are observed. Malaya, as described by Andrew Birtle, a historian at the US Army Center of Military History and avid author of US COIN operations, is a "comparatively limited and straightforward 'emergency'.”" 181 Iraq, on the other hand, is a considerably more complex situation when viewed across the operational environment factors.

\section{4-1-25.}

180 Thompson, Defeating Communist Insurgency, 171; US Army FM 3-24, Counterinsurgency, 1-

${ }^{181}$ Andrew J. Birtle, “PROVN, Westmoreland, and the Historians: A Reappraisal,” Journal of Military History 72 (October 2008), 1247. 
First, the nature of the conflict and the cultural diversity is more dramatic in Iraq. The Malayan insurgency was contained to primarily one ethnic group located in one geographical area, the Chinese squatter farmlands on the edge of the jungle. Therefore, it was easier for the British-Malayan COIN force to isolate the insurgents from their base of support through increased local security and relocation of the Chinese squatters into secure villages. In addition, the insurgents had one primary goal, to form a communist state, which made it easier for the British to counter. The British also enjoyed a long-established relationship with the Malayans, which enabled a high level of cultural and political understanding.

With Iraq, COIN forces confronted a multiplicity of internal groups from all ethnic and religious factions, who not only fought against each other for political, religious, and criminal reasons, but also against the Coalition and GOI security forces. In addition, external influences such as AQI and Iranian elements continued to support destabilization efforts for their own regional purposes. This made it extremely difficult to determine who to isolate from whom. Furthermore, the Iraq insurgency was primarily urban focused, which presented a greater challenge to governance, economics, and stability than a rural based insurgency as seen in Malaya.

Culturally, Iraq's population is highly heterogeneous, and one that the US military had very little interaction with and cultural knowledge of prior to its COIN operations. Therefore, it took a great deal of time and effort to understand the human terrain-the perspectives of the people, their family, tribe, community organization, values, and religion-to understand how local decisions are made and who wields the political and religious power. ${ }^{182}$ Although the US military had been operating in the region since the Gulf War, large-scale interaction with the population was not feasible due to Saddam's paranoia and antagonistic relations with the West. 
The geography of both countries was a crucial factor in how operations were focused and undertaken. Malaya, being a small peninsular country, was easy to isolate with the insurgency receiving little to no external support. In addition, Malaya had a very small population of 4.9 million that was manageable to secure. Iraq, being a large almost exclusively landlocked county with porous borders along two antagonistic countries, made isolation nearly impossible. Therefore, isolation was not fully attempted and the Iraqi insurgents enjoyed external support in terms of money, fighters, equipment, and technology. In addition, with a population of 25-28 million, just securing the population was an enormously difficult task.

Finally, the directed mission was also dramatically different and was a critical factor in the COIN effort. The Malayan COIN forces were supporting an established government, which had the support of the majority of the population. The British utilized and strengthened the local governments through a system of committees, where decisions, both civil and military, were made for their region. In Iraq, the Coalition not only had to build a new form of government, one in which the population had never experienced, but also rebuild Iraq's institutions due to the policy of de-Baathification. This process was even more difficult with the Coalition being predominantly Western and from the fall-out of the decisions the made by the CPA. These factors caused a large portion of Iraqis to view the Coalition as an occupying power and a threat to their religion and culture.

\section{Implications for Planners}

Although each conflict is unique and must be judged accordingly, theoretical principles can be gleaned from their combined analysis. ${ }^{183}$ From these case studies, five important force level implications for COIN emerge. These include, 1) numbers do matter; 2) the size of the US

\footnotetext{
${ }^{182}$ Montgomery McFate, “Anthropology and Counterinsurgency: The Strange Story of the Curious Relationship,” Military Review (March-April 2005), 37; Alford and Cuomo, “Operational Design for ISAF in Afghanistan,” 94.

${ }^{183}$ Birtle, "PROVN, Westmoreland, and the Historians," 1247.
} 
Army will limit its flexibility in future operations; 3) the need to incorporate $\mathrm{HN}$ forces early in operations; 4) strategies will change during operations; and 5) the military alone is insufficient to succeed in a COIN environment.

First, in a COIN environment, numbers do matter. To be successful, the COIN force must have adequate strength to protect the population from the intimidation and physical threats of the insurgents, along with a myriad of other tasks that support the COIN effort, including the crucial task of training of HN security forces. These case studies have shown that the closer force levels approached the 20:1000 ratio, the greater the possibility they will reach the tipping point to success. In addition, both cases required numbers that exceeded the numbers used during conventional operations. ${ }^{184}$ This realization is repeatedly experienced as military planners and civilian leaders underestimate the resources needed for COIN operations. The ability to use hightech, long-range precision strike capabilities and small ground forces with overwhelming firepower works extremely well for the conventional fight, but they are severely mitigated in COIN operations, especially in an urban environment. Consequently, it appears easier "to get in than win” and to "win the war than win the peace.”185

Therefore, these case studies support the 20:1000 planning figure as a guide to provide sufficient resources. As Sir Robert Thompson, a renowned counterinsurgency expert who served in Malaya and was the head of the British Advisory Mission to Vietnam, wrote, "The only two prerequisite and enduring assets are brains and feet. These are entirely human. The side which has its feet on the ground at the right time and in the right place will win.",186

The use of large numbers does not necessarily guarantee success. Yet, small force levels in relation to the population make it difficult to ensure order, especially after major combat

\footnotetext{
${ }^{184}$ McGrath, "Boots on the Ground,” 113.

185 Budiansky, “Formula for How Many Troops We Need.”

186 Thompson, Defeating Communist Insurgency, 171.
} 
operations when HN security forces are degraded. Therefore, mobilizing large force levels early in the operation, in conjunction with civilian and financial assets, makes it easier to restore security and may prevent an insurgency. ${ }^{187}$ After the fall of Baghdad, mass, not speed became the most important requirement for success. ${ }^{188}$

As planners will rarely, if ever work with unconstrained resources, they must understand and articulate the operational risks associated with force levels. From the analysis of the case studies, two likely outcomes can be expected if insufficient forces are used after major combat operations or injected into a failing state. The first is a degraded security environment, which provides fertile grounds for an insurgency to form. The second is a longer and more difficult insurgency to defeat since the insurgency will likely utilize an unstable environment to strengthen its organization and support structures. Although these outcomes are not causal, there is a strong correlation between the level of forces and the ability to defeat an insurgency, or to prevent one from beginning. ${ }^{189}$

Not only having the right force size is important, but also the right force composition. Other than the size of police, which was discussed as being nearly a third of the security force by McGrath and the RAND study, this work has not discussed the composition of the force. Although beyond the scope of this work, it is necessary to have the right forces in the right numbers at the right area.

Second, with the current size of the US military, and especially the Army, its strategic flexibility to conduct future operations will be limited. With populations in many developing regions dramatically increasing, possibly doubling by 2020 particularly in Africa, the Middle East, and South and Southeast Asia, the competition for resources will increase, and likewise the

\footnotetext{
187 Jones, “Establishing Law and Order After Conflict,” 208.

${ }^{188}$ Gordon and Trainor, COBRA II, 499-500.

189 Jones, “Establishing Law and Order After Conflict,” xi-xiii, 208.
} 
chance for more failed or failing states to become safe-havens for adversaries. ${ }^{190}$ What should worry planners is that this population growth will have adverse effects on the US military's range of options when compared against the small size of US land forces. ${ }^{191}$

The US Army’s current active and reserve component size is slightly over a million uniformed members. ${ }^{192}$ When compared with the growing size of the populations in most “troubled” regions of the world, protracted, unilateral COIN operations quickly become unattainable without massive mobilization. ${ }^{193}$ As seen in Iraq, which has the world's 44th largest population and Afghanistan with the 40th, the US military, even with coalition support, struggled to meet the forces requested by commanders. ${ }^{194}$ Therefore, planners will need to consider largescale, coalition-supported operations that would likely require both simultaneous and sequential operations for securing the population. Instead of spreading forces throughout a country to establish security, an approach similar to the one executed in Malaya may be necessary, where the clearing and securing of the population was done in successive "priority areas," while simultaneous applying pressure to insurgent controlled areas, as proposed by both Sir Robert Thompson and David Galula. ${ }^{195}$ With half the world’s population being urbanized by 2015, cities

${ }^{190}$ US Army FM 3-0, Operations, 1-2-1-3; US Joint Forces Command, “The Joint Operating Environment 2008,” 10.

191 Donnelly and Kagan, Ground Truth, 1.

192 Honorable Nelson Ford (Under Secretary of the Army), "Balancing the Force: Considerations of Size, Structure, and Risk,” moderated by Dr. Peter Singer, the Brookings Institute transcript (October 22, 2008), http://www.brookings.edu/events/2008/1022_military.aspx (accessed January 29, 2008), 7, 10. The active force is 540,000, while there are 550,000 in the reserve force.

193 Donnelly and Kagan, Ground Truth, 144. Examples given include Iran and Pakistan.

194 Ford, "Balancing the Force,” 8; CIA World Fact Book, “Population Rank Order,” https://www.cia.gov/library/publications/the-world-factbook/rankorder/2119rank.html (accessed 1 October 1, 2008). Iran's population ranks number 21 with 66 million, while Pakistan is number 8 with 176 million.

195 Thompson, Defeating Communist Insurgency, 57,111-115; David Galula, Counterinsurgency Warfare, chap. 5; McGrath, "Boots on the Ground,” 38. 
themselves will become increasing difficult to control, especially mega and metacities with large slum populations. ${ }^{196}$

These large populations lead to the third implication, which is the requirement for units to incorporate and partner with HN security forces in COIN operations. In fact, doctrine states that while combat operations may be necessary, they are secondary to enabling the HN to provide for its own security. ${ }^{197}$ In the end, the HN has the final responsibility for finding the right elements for a lasting victory, which requires effective HN security forces to provide security for the populace and to strengthen the legitimacy of the HN government. ${ }^{198}$

Clearly, there are several advantages to utilizing HN forces. Most pertinent to this discussion is that the addition of HN security forces will increase the size of the COIN force, enabling them to attain the 20:1000 ratio quicker, while utilizing less US and coalition forces. In addition, $\mathrm{HN}$ forces are usually more effective in the conduct of population security, once trained and equipped, than foreign forces. This is partially due to their inherent advantages, including understanding the local culture, social structures, and language. They also have the ability to more effectively gain the trust of the local populace and to obtain human intelligence on the insurgents, which are all critical capabilities in a COIN environment that can take foreign forces years, if ever to achieve. Finally, at the local level, true security is only achieved with the presence of a legitimate local police force that is of and for the people. ${ }^{199}$ General Abrams captured these points when he remarked about the Peoples Self-Defense Force in Vietnam saying,

${ }^{196}$ US Army FM 3-0, Operations, 1-2; US Joint Forces Command, “The Joint Operating Environment 2008," 40; UN-Habitat, “Urbanization: Mega and Meta Cities, New City State?,” State of the Worlds Cities, 2006/7, http://ww2.unhabitat.org/mediacentre/documents/sowcr2006/SOWCR\%202.pdf (accessed 9 March 2009).

${ }^{197}$ US Army FM 3-24, Counterinsurgency, 6-2.

${ }^{198}$ US Army FM 3-24, Counterinsurgency, 1-26, US Joint Forces Command, “The Joint Operating Environment 2008,” 47.

${ }^{199}$ Alford and Cuomo, “Operational Design for ISAF in Afghanistan,” 96. 
“There isn’t anybody in this country who can work as well with the people and get along as well with the people, enjoy the confidence of the people, the way those people can.”200

As seen in Iraq and Malaya the regular, professional militaries deployed were wholly insufficient in numbers to secure the populations. Only once large numbers of HN security forces were organized, trained, and deployed was the security effort successful and the COIN objectives achieved. However, the tasks of building HN security force capability, sustainability, and partnership takes time and must begin early in the operation, as soon as conditions merit. A key element to this effort is the advisor and having trained and deployable advisor units ready for the task at the beginning of the operation. ${ }^{201}$ The problem in Iraq, however, was not the realization of HN security force importance, but having a training plan ready to execute. Once the Coalition's assumption of being able to use large numbers of established Iraqi security forces proved invalid, they had to develop a plan for training, equipping, and funding a new Iraqi force, which cost precious time. $^{202}$

Fourth, COIN strategies will change and adapt during operations. In complex environments, such as COIN where the war is amongst the people and the adversary learns and adapts, “there are no final solutions” as David Galula advised. ${ }^{203}$ This will not change in the future, but what is critical for planners is to anticipate this need and to match the resources, both military and nonmilitary (means) to the theater-strategic objectives (ends) through the application

${ }^{200}$ Sorley, A Better War, 73.

${ }^{201}$ Donnelly and Kagan, Ground Truth, 107; US Army FM 3-24, Counterinsurgency, 6-17.

${ }^{202}$ Gordon and Trainor, COBRA II, 466-467; Wright and Reese, On Point II, 475-476. The first year of ISF training was largely improvisation by Coalition Special Forces. With the establishment of MNSTC-I in June 2004, ISF training become a dedicated effort under one headquarters, but the building of the ISF was still slow, with the first noticeable results being the security for the January 2005 elections.

${ }^{203}$ Galula, Counterinsurgency Warfare, 137; School of Advanced Military Studies, “Art of Design," 9-10. 
of operational art into a campaign plan (ways). ${ }^{204}$ The authors of On Point captured this point

well when they describe the initial operation in Iraq:

The oft-stated goal of regime change implied some degree of postwar steps to build a new Iraqi Government in place of the Saddam regime. Regime removal might have been a more accurate description of the goal that the design of OIF was best suited to accomplish. The military means employed were sufficient to destroy the Saddam regime; they were not sufficient to replace it with the type of nation-state the United States wished to see in its place. ${ }^{205}$

Therefore, the number of troops should not be arbitrarily determined, but based upon the mission and objectives that are to be accomplished in achieving the strategy. As is natural in war, both ends and means will constantly shift based on conditions, as war is not a static endeavor. As the strategy adjusts, planners must rebalance the means. ${ }^{206}$ However, when the character of the war being fought is COIN, the strategy, and subsequently the force size must be nested with providing security for the people.

As seen in Malaya and Iraq, the strategy adapted to meet the threat and regain the initiative. In both conflicts, the strategy initially focused on large-scale operations, directed at defeating the insurgents militarily. After they failed, both adapted COIN-focused strategies that placed the population's security as the priority. The resources were also adjusted to meet the new strategic aims. In Malaya, Templer needed to increase forces to fully implement the "Briggs Plan” to secure the rural population. He did this through increasing the police force, the Home Guards, and the Special Constables. In Iraq, President Bush acknowledged that his previous

\footnotetext{
${ }^{204}$ US Joint Forces Command Joint Publication 5-0, Joint Operation Planning, chap. IV; US Joint Forces Command Joint Publication 3-0, Joint Operations, GL-21; US Army FM 3-0, Operations, 6-4-6-5. As defined in Joint Publication 3-0, operational art is "the application of creative imagination by commanders and staffs-supported by their skill, knowledge, and experience-to design strategies, campaigns, and major operations and organize and employ military forces. Operational art integrates ends, ways, and means across the levels of war."

${ }^{205}$ Wright and Reese, On Point II, 569.

${ }^{206}$ Dubik, “No Holy Grails, No Silver Bullets,” 18-20.
} 
attempt of clear-hold-build in Baghdad did not have adequate forces, and therefore sent the “surge” forces to Iraq.

Fifth, the military alone is insufficient to achieve the strategic objectives in a COIN environment. Military efforts are necessary, but are only effective when integrated into a comprehensive strategy employing a whole of government approach. ${ }^{207}$ To succeed, a coherent political-military strategy is required. Such a strategy is devised through an understanding of the cultural, religious, political, social, and historical context within which the war is being fought. This strategy must also be resourced for a long-term commitment. ${ }^{208}$ Again, the aim is to eliminate the causes of the insurgency, thereby rendering them irrelevant, rather than attempting to kill or capture every one of them. ${ }^{209}$ Planners must be cognizant that COIN is not primarily a military effort, but rather a political one. David Galula clearly identified this point when he wrote:

What is at stake is the country's political regime, and to defend it is a political affair. Essential though it is, the military action is secondary to the political one, its primary purpose being to afford the political power enough freedom to work safely with the population. $^{210}$

Just as clear is the need for a coordinated and tandem effort of both civil and military initiatives. The security environment, the health of the economy, and capability of government are interdependent, as shown in figure $2 .{ }^{211}$ Political, social, and economic reforms require time and a stabilized population that is free of insurgent intimidation. Lasting security, however, requires the support of the people, which is dependent upon the people's confidence that the government has the will, means, and ability to succeed against the insurgents and improve their

\footnotetext{
${ }^{207}$ US Army FM 3-24, Counterinsurgency, 2-1; US Army FM 3-07, Stability Operations, 1-4.

${ }^{208}$ US Joint Forces Command, “The Joint Operating Environment 2008,” 46.

${ }^{209}$ US Army FM 3-24, Counterinsurgency, 2-1.

${ }^{210}$ Galula, Counterinsurgency Warfare, 89.

${ }^{211}$ US Army FM 3-0, Operations, 3-13.
} 
quality of life. ${ }^{212}$ Without security, the local economy and governance falters. A functioning economy provides employment and reduces the dependence of the population upon the military for necessities, but also provides income for the government to support the security forces, enable governance, and provide essential services. ${ }^{213}$ Information engagement is required to build popular support for the government by informing the populace of government policies and accomplishments, as well as by undermining insurgent propaganda. ${ }^{214}$ Therefore, success requires all elements of national power. Achieving victory, according to Galula, is not only the destruction of the guerrillas and their political-military organization, but also the permanent isolation of the insurgents from the population, maintained by the population. This requires the mobilization of the population against the insurgents, with every effort, being political, social, economic, informational and military, geared toward that end. ${ }^{215}$

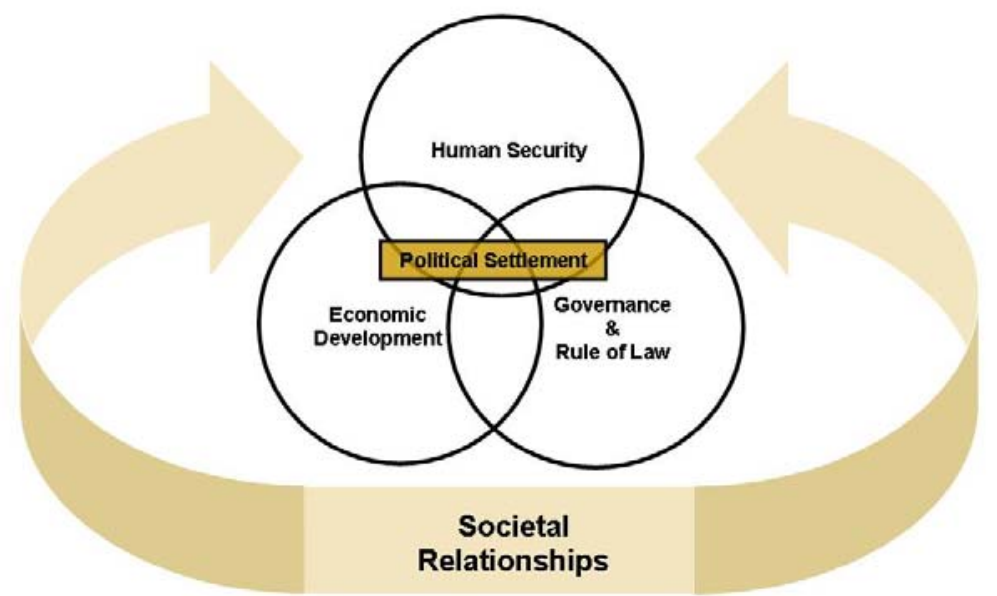

Figure 2. Elements of a Stable State. ${ }^{216}$

212 Galula, Counterinsurgency Warfare, 75, 78, 79.

213 US Army FM 3-0, Operations, 3-13.

${ }^{214}$ US Army FM 3-24, Counterinsurgency, 5-8; US Army FM 3-0, Operations, 7-3-7-5.

${ }^{215}$ Galula, Counterinsurgency Warfare, 77.

${ }^{216}$ NATO AJP 3.4.4 (Draft), Allied Joint Publication for Counterinsurgency (COIN), November 2008, 11. 
In Malaya and Iraq, both COIN forces began their operations lacking unity of effort for their civil-military initiatives in both policy and execution. ${ }^{217}$ Although initially disjointed, unity of effort for military and civil functions was later achieved through the establishment of Templer’s new command structure in Malaya, and the Coalition's establishment of MultiNational Force-Iraq (MNF-I). ${ }^{218}$ Both commands had the responsibility for coordinating not only the whole of government support from foreign and HN governments, but also translating theaterstrategic objectives into a coordinated effort of both military and civil operations. Tactical operations (be it a battalion or provincial reconstruction team) often have operational and strategic effects in COIN environments. If tactical units are employed uncoordinated or focused on the wrong objectives, they could negatively impact the overall COIN effort and create, although inadvertently, more adversaries. ${ }^{219}$

\section{Application of Force Level Analysis to Afghanistan}

This section will apply the quantitative and qualitative analysis from the case studies to the contemporary operations in Afghanistan. This analysis is not to be viewed as second-guessing the US, international, and Afghan leadership currently conducting operations, but as a means to translate the theoretical principles and lessons from the case studies into a practitioner's application for Afghanistan.

${ }^{217}$ Wright and Reese, On Point II, 373, 427, 571; Komer, “The Malayan Emergency in Retrospect,” 26. In Iraq examples include the lack of planning for post-Saddam reconstruction, the issue of de-Baathification, the changing of commands, both military and civilian during the transition to phase IV, and the division between CPA and CJTF-7 about the training of ISF. In Malaya, examples include the overlapping police and military efforts and unclear divisions of responsibility between civil and military authorities due to a "committee" structure.

${ }^{218}$ Wright and Reese, On Point II, 172-172; Komer, “The Malayan Emergency in Retrospect,” 30. In Iraq, MNF-I was a new headquarters formed in 2004 to provide theater-strategic and operational-level command and control for all Coalition forces in Iraq. It also provided support to CPA and the US Embassy, as well as to the emerging Iraqi Government. In Malaya, Templer under direction from Churchill, devised a new post by merging the positions of High Commissioner and Director of Operations into the High Commissioner in 1952. As the head of this post, Templer was in charge of the civil authorities, while as senior military officer he was empowered to issue direct operational orders to the armed forces.

${ }^{219}$ Alford and Cuomo, “Operational Design for ISAF in Afghanistan,” 93. 
In October 2001, the US began a campaign called Operation ENDURING FREEDOM (OEF) to overthrow of the Taliban regime in Afghanistan. ${ }^{220}$ This military action was in response to the Taliban's alliance with and support for al-Qaeda, which conducted terrorist attacks against the US mainland on September 11, 2001. With the Taliban's support, al-Qaeda established several large-scale permanent bases and training camps in Afghanistan from which they planned and conducted global terrorist operations. ${ }^{221}$ The US strategic objectives were to remove the Taliban regime to prevent Afghanistan from continuing to provide safe-haven and support for alQaeda, which would also assist US forces in capturing Osama Bin Laden and destroying alQaeda. $^{222}$

With the fall of Kabul in November and Kandahar in December of 2001, the Taliban regime was essentially destroyed with only pockets of Taliban and al-Qaeda fighters remaining. The Taliban's removal was done through a combination of US Special Operations Forces, air power, and Afghan forces including the Northern Alliance and Pashtun anti-Taliban forces. ${ }^{223}$ However, in 2003, Taliban forces began to reorganize and launched a renewed struggle to overthrow the Afghan government and coerce the withdrawal of the US-led Coalition. ${ }^{224}$ Although the level of insurgent activity remained manageable for the first few years, the low Coalition force levels could not prevent the Taliban from rapidly increasing their strength and number of attacks in 2006. ${ }^{225}$ The escalation continued into 2007 and 2008 as the Taliban and

\footnotetext{
${ }^{220}$ Kenneth Katzman, “Afghanistan: Post Taliban Governance, Security, and U.S. Policy,” Congressional Research Service, Order Code RL30588 (February 9, 2009), http://www.fas.org/sgp/crs/row/RL30588.pdf (accessed March 12, 2009), 6-7.

${ }^{221}$ Donnelly and Kagan, Ground Truth, 47.

${ }^{222}$ Katzman, “Afghanistan,” 6.

223 Ibid., 7; Jones, “Establishing Law and Order After Conflict,” 61.

${ }^{224}$ Seth G. Jones “Counterinsurgency in Afghanistan,” RAND study prepared for the Office of the Secretary of Defense (Santa Monica, CA: RAND Corporation, 2008), 30.

${ }^{225}$ Katzman, “Afghanistan,” 24; Jason H. Campbell and Jeremy Shapiro, “Afghanistan Index: Tracking Variables of Reconstruction and Security in Post-9/11 Afghanistan,” January 2009, (Washington
} 
anti-government elements doubled their number of attacks, resulting in a severe deterioration in the Afghan security environment. They have also increased the area characterized as having a heavy Taliban presence from 54 to 72 percent of the country. ${ }^{226}$ The year 2008 recorded the highest number of US combat casualties, the highest number of suicide bombings and IEDs, and the highest number of high profile attacks in Afghanistan. ${ }^{227}$

In analyzing the quantitative factors affecting force levels in Afghanistan, the current size of the population and security force levels are determined. Currently, Afghanistan has an estimated population of 33.6 million. ${ }^{228}$ Using the 20:1000 planning ratio as a gauge to determine the necessary force levels to secure the population while also conducting FSO and HN security force training, a rough estimate of 672,000 security forces is calculated.

Like Iraq and Malaya, security forces include the external and HN police and military forces. ${ }^{229}$ The international security forces in Afghanistan, including US forces, are divided between the NATO-led International Security Assistance Force (ISAF) and the US-led multinational force of Operation Enduring Freedom (OEF). ${ }^{230}$ ISAF has a force level of 55,100,

D.C.: The Brookings Institute, 2009), http://www.brookings.edu/foreign-policy/afghanistan-index.aspx (accessed March 10, 2009), 5.

${ }^{226}$ Taliban and anti-government elements have increased their attacks between 2007 and 200851 percent nationwide, 48 percent in Kabul, 39 percent in RC-East, 77 percent in RC-South, and a 37 percent increase on attacks along Afghanistan's major highway, the "Ring Road." Campbell and Shapiro, "Afghanistan Index," 16; US Department of Defense, "Progress Toward Security and Stability in Afghanistan,” January 2009, Report to Congress in accordance with the 2008 National Defense Authorization Act (Section 1230, Public Law 110-181), http://www.defenselink.mil/pubs/OCTOBER_1230_FINAL.pdf (accessed March 10, 2009), 31; International Council on Security and Development (ICOS) maps, http://www.icosmaps.net/ (accessed March 14, 2009).

${ }^{227}$ Katzman, “Afghanistan,” 26.

${ }^{228}$ CIA World Fact Book, "Population Rank Order.” This is a very rough estimate since the last census was conducted in 1979.

${ }^{229}$ US Army FM 3-24, Counterinsurgency, 1-13.

${ }^{230}$ US Department of Defense, “Progress Toward Security and Stability in Afghanistan,” 27. 
while OEF has a much smaller force with $19,000 .{ }^{231}$ To effectively conduct COIN operations in Regional Command (RC)-East and South (figure 3), where the majority of the insurgent attacks are taking place, US President Obama responded in February 2009 to General David McKiernan's, the Commander of ISAF and US Forces Afghanistan (OEF Forces) requests for more forces by ordering 17,000 additional forces. ${ }^{232}$ In addition to external forces, Afghan National Security Forces (ANSF) has a total of 155,000 between the Afghan National Army (ANA) and Afghan National Police (ANP). ${ }^{233}$ Together, a total COIN security force of 246,100 is available, which produces a troop density ratio of 7.3 per thousand population. This low figure creates an enormous delta of nearly 427,000 security forces, which will clearly take extensive troop contributions from both $\mathrm{HN}$ and international partners to attain the necessary resources to establish widespread security.

\footnotetext{
${ }^{231}$ Campbell and Shapiro, “Afghanistan Index,” 10; US Department of Defense, "Progress Toward Security and Stability in Afghanistan,” 8, 27. These figures are as of January 2009.

${ }^{232}$ Campbell and Shapiro, "Afghanistan Index,” 16; Elisabeth Bumiller, "General Sees Long Term for Afghanistan Buildup,” New York Times, February 18, 2009, http://www.nytimes.com/2009/02/19/washington/19pentagon.html?ref=world (accessed March 12, 2009); US Department of Defense, "Progress Toward Security and Stability in Afghanistan," 27. Combined, RCEast and South contained 4,813 of the 5,601 total attacks in 2008 (86 percent).

${ }^{233}$ US Department of Defense, "Progress Toward Security and Stability in Afghanistan,” 7-9, 35, 42, 48. ANA have approximately 79,000 soldiers as of December 2008, while the ANP has a force of 76,000 as of November 2008. The ANP numbers include the Afghan Border Police (ABP), the districtlevel Afghan Uniformed Police (AUP), national-level Afghan Civil Order Police (ANCOP), and Counternarcotics Police of Afghanistan (CNPA). To increase the ANA, the international Joint Coordination and Monitoring Board (JCMB) approved an increase proposal from an authorized strength from 80,000 to 134,000 by October 2013. The training and effectiveness of ANSF also needs to be considered. The ANA has a very solid reputation and continues to demonstrate increasing competence, effectiveness, and professionalism. As of December 2008, 44 of 83 battalions (kandaks) were at Capability Milestone (CM) 1 and 2, which means they are capable of operating independently or capable of planning, executing, and sustaining COIN operations at battalion level with international support, respectively. The ANP, however, continue to be hampered by lack of reform, widespread corruption, and lack of international trainers. As of December, the ANP had 34 CM 1and 2 units from 373. Likewise, the ANP is programmed to expand to 432 ANP units from the current 373 by 2013. Clearly, ANA and ANP increases will help, but only raise the ratio to 9.3 (an increase of approximately 67,000 forces) if all other force levels remain constant.
} 


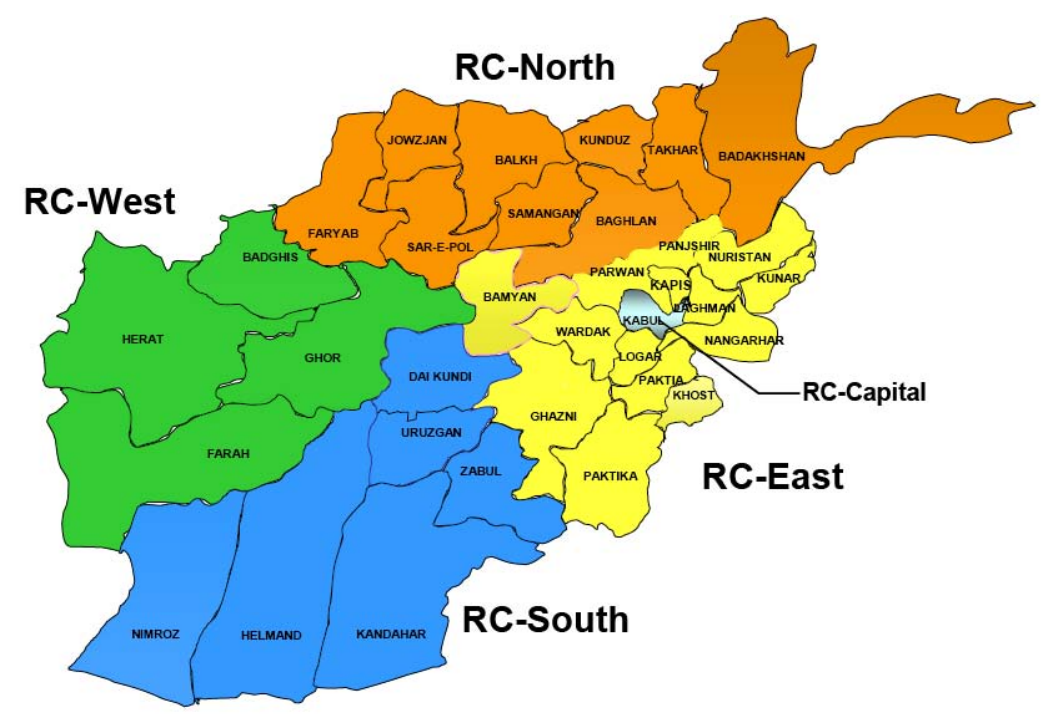

Figure 3. ISAF Regional Commands ${ }^{234}$

Although the quantitative analysis of forces levels in Afghanistan is fairly straightforward, the qualitative analysis is extremely difficult. This is because of the complex nature of both the insurgency and the operational environment of Afghanistan. This complexity is apparent upon examining the expanding militant presence in areas previously considered secure, and the increased numbers of civilian and military deaths. The Taliban resurgence is fueled by the growing disillusionment of the Karzai-led Afghan government with its widespread corruption, the narcotics trade, and the inability of both Afghanistan and Pakistan governments to prevent the Taliban attacks being launched from the sanctuary of Pakistan’s Federally Administered Tribal Areas (FATA) and North West Frontier Provence (NWFP). This problem set has led the Obama Administration to conduct a sweeping review of the Afghan strategy. ${ }^{235}$ Due to the complexity and sheer number variables that impact force levels, a comprehensive analysis of Afghanistan's security environment is beyond the scope of this work, but a few of the main security challenges will be discussed.

\footnotetext{
${ }^{234}$ US Department of Defense, “Progress Toward Security and Stability in Afghanistan,” 28.

${ }^{235}$ Katzman, “Afghanistan,” summary.
} 
The first challenge is the nature of the insurgency. The Afghan insurgency primarily consists of the Taliban, but also contains warlords, criminals, and foreign fighters. ${ }^{236}$ The Taliban’s historical base of support is mainly among the Pashtun, the largest ethnic group in Afghanistan who reside primarily in eastern and southern Afghanistan. ${ }^{237}$ This is important since the Pashtun tribes also extend over the Durand Line into Pakistan's FATA and NWFP. This provides the Taliban not only external sanctuary, but associations with other militant organizations including the Pakistani Taliban and al-Qaeda. ${ }^{238}$

Al-Qaeda is a key actor in the Afghan insurgency. Al-Qaeda continues to facilitate the insurgency through financial support and recruits. By taking advantage of a Afghanistan’s environmental factors, including the enormous poverty of the Afghan population, the Pashtun's historical desire for high levels of regional autonomy and aversion to foreign forces, the lack of government penetration outside of Kabul, and the outrage over collateral damage from US and NATO airstrikes, al-Qaeda continues to leverage the Taliban in support of their ideological war against the West. ${ }^{239}$ Another means of support for the insurgency is the extremely lucrative narcotics trade. Over 93 percent of the world's opium is cultivated in Afghanistan, primarily the southern, Taliban influenced region. ${ }^{240}$ These challenges, including the Taliban's relatively safe sanctuary in Pakistan, the narcotics trade, and the influence of al-Qaeda, makes Afghanistan’s insurgency a regional problem that requires regional cooperation if an acceptable outcome is to be

${ }^{236}$ Katzman, “Afghanistan,” 4, 12, 23-24; Jones, “Establishing Law and Order After Conflict,” 62.

${ }^{237}$ Katzman, “Afghanistan,” Table 1, 3; National Geographic, "Understanding Afghanistan: Land in Crisis,” http://www.nationalgeographic.com/landincrisis/ethnic.html (accessed March 14, 2009).

${ }^{238}$ Jayshree Bajoria, “al-Qaeda,” Council on Foreign Relations, (April 18, 2008), http://www.cfr.org/publication/9126/ (accessed 14 March 2009); Katzman, “Afghanistan,” 46. The "Durand Line," is a border agreement reached between Britain (signed by Sir Henry Mortimer Durand) and then Afghan leader Amir Abdul Rahman Khan in 1893, separating Afghanistan from what was then British controlled India (later Pakistan after the 1947 partition).

${ }^{239}$ Bajoria, "al-Qaeda,"; US Department of Defense "Progress Toward Security and Stability in Afghanistan,” 31; Katzman, “Afghanistan,” 27. 
achieved. These factors have also enabled the Taliban to coalesce into a resilient and continually evolving insurgency. ${ }^{241}$

Another significant challenge is Afghanistan’s geography. Simply stated, Afghanistan’s rugged terrain and harsh climate have historically presented significant obstacles to not only foreign invaders, but also the ruling authority. Being an extremely mountainous and desolate country, the vast majority of Afghanistan’s rural population lives a medieval-type life of unreliable food corps for subsistence and some, opium-poppy cultivation for income. ${ }^{242}$ Centralized governance in Afghanistan is very difficult, as only 23 percent of the population is urbanized, and Afghanistan suffers from the lack of infrastructure, including roads, energy, communications, health, and education. With little domestic income, Afghanistan ranks as one of the poorest countries in the word. ${ }^{243}$ Besides portraying a bleak economic outlook, these factors also greatly affect the security environment. Together, the low urbanization, poor infrastructure, and insufficient domestic revenue, the government is greatly limited in their ability to expand their influence to the population and to provide for their basic needs, including security. With Afghanistan being nearly the size of Texas, the few available security forces quickly become consumed by the rugged terrain, vast size, and dispersed population. ${ }^{244}$

Finally, the historical and cultural aspects of the Afghan people are a significant challenge to the security environment. Afghanistan has historically lacked a strong central government. Instead, Afghan territory has been controlled by tribes and local strongmen with its

${ }^{240}$ US Department of Defense, "Progress Toward Security and Stability in Afghanistan,” 9. Helmand province alone accounts for 66 percent of the poppy cultivation.

${ }^{241}$ US Department of Defense, "Progress Toward Security and Stability in Afghanistan," 7.

${ }^{242}$ Harm De Blij, Why Geography Matters: Three Challenges Facing America (New York: Oxford University Press, Inc., 2005), 157-159.

${ }^{243}$ US Department of Defense, "Progress Toward Security and Stability in Afghanistan,” 11-12; United Nations Children’s Fund (UNICEF), Afghanistan Demographics Statistics, http://www.unicef.org/infobycountry/afghanistan_statistics.html\#48 (accessed March 17, 2009).

${ }^{244}$ Blij, Why Geography Matters, 157-159. 
inhabitants pledging loyalty to those with similar kinship ties and patrilineal descent, rather than to the state. Even the British and the Soviets were unable to destroy tribal power and establish a strong centrally controlled state. Therefore, the Afghan governments have never successfully established a monopoly of the legitimate use of force over the country. To maintain order and control, the Afghan tribes have undertaken this responsibility themselves. ${ }^{245}$ Among the Pashtun populations, tribal rule is conducted through the jirga (tribal council) which meets to address specific issues. The Pashtuns also live under the traditional tribal code of pashtunwali. This custom is a major influence that guides their way of life and is based upon the principles of honor, equality, and retaliation. To protect the tribe or village, the traditional security institution is the lashkar, which is a collection of armed male members from the families. ${ }^{246}$

Recently, there has been a shift in US and NATO strategy to build security through local governance. The approach has been to restore the traditional tribal and local structures, and to strengthen their relationships with the central government. ${ }^{247}$ In late 2008, the Bush Administration and Karzai government reached an agreement to arm some local tribal militias (arbokai) in eastern Afghanistan. Termed the “Community Guard” program, it is intended to strengthen the ability of local communities to keep Taliban infiltrators out. ${ }^{248}$

With the low COIN-force levels, it seems prudent to work within the propensity of the Afghan tribal system to achieve stability in the eastern region. This approach is consistent with the COIN imperative of working with and through the HN. With the current force levels, building ties of cooperation with the tribes and local leaders is essential. As General McKiernan stated, “...we are, at best, stalemated, and we need additional, persistent security presence in areas that

245 Jones, “Establishing Law and Order After Conflict,” 64-66.

${ }^{246}$ Major components of Pashtunwali are melmastia (hospitality), nanawati (sanctuary), badal (revenge) and nang (honor). Presentation by Dr. Wilhelm to SAMS seminar in October 2008.

${ }^{247}$ Katzman, “Afghanistan,” 15-16.

${ }^{248}$ US Department of Defense, “Progress Toward Security and Stability in Afghanistan,” 30. 
we're not at today. I have to tell you that 2009 is going to be a tough year." ${ }^{\text {,49 }}$ The question remains, however, if the Pashtuns with their segmentary tribal society based upon close family ties can be co-opted on a large scale, similar to the SoI experience in Iraq.

Clearly, the operational environment in Afghanistan is significantly more complex than Iraq, and certainly more so than Malaya. Therefore, it is logical to assume that a COIN security force greater than 20:1000 will be required to establish a stable environment. With a quantitative force level shortage of over 400,000, achieving stability is going to be extremely difficult. To mitigate the quantitative shortage, additional internal and external forces are clearly required, but the qualitative aspects affecting force levels must also be optimized. The Afghan government, Pakistan government, and Coalition partners must work to improve the political situation in the region. This includes political reconciliation, reduced corruption, and increased support for tribal structures to undermine and discourage insurgent, terrorist, and criminal activity.

\section{Conclusion}

To "win” a counterinsurgency, some commanders, planners, and civilian officials would prefer to focus military efforts on offensive operations against the insurgents, since they feel they are taking the fight to the enemy. Although emotionally appealing, this approach is dysfunctional as securing the population is the paramount military objective. To "hold" what has been "cleared" is often the decisive operation in setting and maintaining the conditions for the "build" phase. ${ }^{250}$ Holding-establishing continuous security for the population and host-nation governance at the local level-not only allows for the attainment of the primary objective in a COIN environment, which is the establishment of effective governance by what the people view as a legitimate

\footnotetext{
${ }^{249}$ Bumiller, “General Sees Long Term for Afghanistan Buildup.”

${ }^{250}$ Donnelly and Kagan, Ground Truth, 64.
} 
government, but requires large numbers of forces to do so. ${ }^{251}$ To succeed, the COIN force must be with the people. ${ }^{252}$ To be with the people, the COIN force must have the appropriate means.

Although no two COIN environments are the same (vis a vis Iraq and Afghanistan), the primary principle of securing the population is a constant. To better evaluate the resources needed to accomplish this task, along with other critical COIN tasks, this monograph has presented five population-based force ratio theories for planners to analyze and consider for their particular mission, along with six operational environmental factors to adjust troop levels for their unique environment. Each of the force ratio theories differ based upon the authors analysis of historical data and the case studies selected. However, the most applicable theory for counterinsurgency operations, as determined from this study using the case studies of Malaya and Iraq, is the one stated in US doctrine of 20 security forces per 1000 population. This should be the starting ratio, then revised higher or lower based on the situation's unique environmental considerations. This ratio provides the resources needed to conduct full spectrum operations-protecting the population while conducting offensive operations to defeat insurgent activities and remove irreconcilable insurgents, while also undertaking stability operations to improve governance, essential services, and economics-and execute the myriad of other tasks that support the COIN effort, including the crucial task of training of host-nation security forces.

It is important to remember that conflict is inherently complex, unpredictable, and there are no final solutions. Especially when the fight is for the population's support, non-deterministic human behavior will inevitably impact the operational environment in unpredictable ways. ${ }^{253}$ War is still an art and historical figures applied to the future can be educational and insightful, but they do not guarantee success. Policy makers, commanders, and planners should use these

\footnotetext{
${ }^{251}$ US Army FM 3-24, Counterinsurgency, 1-21, 5-18-5-20.

${ }^{252}$ Donnelly and Kagan, Ground Truth, 90.
} 
theories and environmental factors as a planning guide and adapt where required. These tools should augment, not replace the creative thinking and sound planning required for success.

The case studies of Malaya and Iraq also provide lessons that can be applied to future COIN environments. First, COIN operations cannot be accomplished "on the cheap.” COIN operations require a persistent effort with a high level of resources. As the case studies have shown, there must be sufficient forces to dominate the operational area on a constant basis, as well as conduct offensive operations to disrupt the insurgent networks and activities. With the central issue being a contest for political power, only through securing the population from insurgent violence and intimidation will the host-nation government and international partners have the ability to apply the other elements of national power to decisively win the population's support and acceptance of the government as the legitimate authority.

Another lesson is not to underestimate the insurgents or the resources needed. COIN will likely require more forces than a preceding conventional war. In addition, it is best to deploy a large force at the onset of an insurgency when the enemy is still attempting to gain a foothold, and their organization has not had the opportunity to solidify. To acquire sufficient forces, hostnation security forces must be incorporated into the COIN effort as quickly as possible. Therefore, a host-nation training plan must be on hand and resourced, ready for implementation at the earliest opportunity.

Finally, COIN requires a coordinated civil-military strategy. A deep understanding of the nature of the conflict is needed to devise an effective, comprehensive strategy that addresses the political-military nature of the conflict. A coordinated strategy with adequate force levels is required to provide the government the time and stability needed to address the political, social,

${ }^{253}$ James M. Mattis, “USJFCOM Commander’s Guidance for Effects-based Operations,” Parameters 38, no. 3, US Army War College Quarterly (Autumn 2008): 24. 
and economic causes of an insurgency. In the end, it takes a comprehensive strategy and sufficient resources-the soldiers and leaders to execute that strategy-to succeed.

None of the comments made are completely new, as the United States has long been adept at executing “small wars.” From our Nation's creation and trials on the Indian frontier, the Philippines, the Banana Wars, and now Afghanistan and Iraq, the US military has a long history of fighting campaigns set by limited objectives, with limited resources, and by relatively small numbers of professional soldiers. ${ }^{254}$ However, from the beginning of Air-Land Battle until the publishing of FM 3-24, Counterinsurgency in 2006, the US Army showed little interest in expending its intellectual capital on these COIN-focused concepts and lessons. This monograph should help fill this void in guidance for force level planning in COIN operations. In the end, independent of the size or type of the conflict, the American public's expectation is the same: victory. In a COIN environment, this entails establishing security for the civilian populace, which requires sufficient "boots on the ground."

${ }^{254}$ Max Boot, The Savage Wars of Peace: Small Wars and the Rise of American Power (New York: Basic Books, Perseus Books Group, 2002) xiv. 


\section{APPENDIX A Quantitative Considerations}

\section{Quantitative Factors Affecting Troop Density for COIN}

Host-Nation Demographics:

Size of the population that needs to be secured or protected

\section{Host-Nation Security Forces:}

Size of army units operational

Size of police units operational

Size of para-military units operational

\section{External Military and Political Factors:}

Size of US Army forces available

Size of international/coalition military forces available

Size of international police support available

Size of private contracted security support available

Political limitations and constraints on the size of force

Host-nation political limitations and constraints on the size of force (if operating in a supporting role to a host-nation government) 


\section{APPENDIX B Qualitative Considerations}

\section{Qualitative Factors Affecting Troop Density for COIN}

Nature of the Conflict:

Internal threats including insurgent goals, motivation, doctrine, and strategy

Level of criminality, warlords, and instability

External threats and level of support for opposition/insurgents

Host-nation political situation

Oppressive or unrepresentative governance

\section{Directed Operations:}

Type of missions, roles, and objectives

Regime change (implies conducting nation-building)

Support existing government against internal threat

Occupation of territory w/o regime change or government support

Regime removal (implies not conducting nation-building)

Corresponding political/military COIN strategy

\section{Local and Regional Culture:}

Cultural and societal tensions-ethnic, religious, racial, ideological

Level of cultural heterogeneous and multiplicity

Historical acceptance or obedience to rule of law

Centralized or decentralized authority norms

Militant culture (high tolerance for violence)

\section{Geography and Population:}

Country size

Country borders-easily porous or isolated

Terrain supportive of insurgents-jungle, mountainous, urbanization

Population distribution, density and location

Demographics-\% military aged males, median age, employment rate

\section{Timing:}

Duration of major combat operations

Duration of instability

\section{Political Factors:}

Host-nation political limitations and constraints

Host-nation political situation

Peace agreement signed or formal surrender by government

Strong central government or strong local/tribal rule

Democratic or authoritarian regimes

Population's perception of mission and foreign forces as

liberators or occupiers-level of resistance to foreign forces

Population's support for host-nation government

Host-nation government's ability to reconcile with factions 


\section{APPENDIX C Summary of Troop Density Ratios}

\section{Theories:}

\section{Quinlivan's Continuum of Ratio's:}

Low violence (police operations): 1-4 security forces per 1000 of population Medium violence (civil unrest): 5-10 security forces per 1000 of population

High violence (insurgency):10+ security forces per 1000 of population-usually requires support of external forces

\section{Current Doctrine-FM 3-24 Ratio:}

20-25 security forces per 1000 of population

20 security forces per 1000 of population is considered minimum for COIN operations

\section{McGrath Ratio:}

13.26 security forces per 1000 of population

\section{RAND Study Ratio:}

13.5 security forces per 1000 of population 10 military forces per 1000 of population

3.5 (international and domestic) police forces per 1000 of population

\section{Brown Ratio:}

10 security forces per 1000 of population

\section{Ratios from Case Studies:}

Malaya: Initial ratio of 4.4, Tipping point ratio of 20.8

Iraq: Initial ratio of 5.7, Tipping point ratio of 16.8 (19.3 with inclusion of SoI)

Afghanistan: Current ratio of 7.3 (estimated ratio of 9.3 with scheduled force increases) 


\section{APPENDIX D Implications for the Modular Brigade}

The modular concept is important to the issue of force levels. The current operational environment requires a responsive land force that can support the diverse requirements of full spectrum operations. To better meet the requirements of the geographic combatant commanders, the Army developed the capability to tailor and task organize expeditionary force packages. This capability is the basis of the modular concept, with the Army’s basic warfighting unit shifting from the division to the brigade. ${ }^{255}$ To hedge against uncertainty and provide more options for political and military leaders, the US Army's modular brigade combat teams (BCTs) and support brigades are expected to be a versatile, multi-purpose force capable of conducting operations across the spectrum of conflict. In addition, BCTs are to be more flexible and responsive than larger divisional units, without sacrificing combat power. To this end, the Army standardized the brigades into three designs: heavy, infantry, and Stryker. ${ }^{256}$

Although modular brigades are currently conducting successful operations in Iraq, from a troop density perspective it is clear the modular concept has some important advantages and disadvantages for COIN operations. The major advantages include smaller force packages that increase operational responsiveness and flexibility, a flattened and more effective command and control structure with improved digital information systems, more organic enablers, and the ability to be better force-tailored. The major disadvantages include the loss of a third maneuver battalion and a shortage of critical combat support and service support units for long-term COIN and stability operations.

${ }^{255}$ US Army FM 3-0, Operations, appendix c.

${ }^{256}$ US Army FM 3-0, Operations, appendix c; Ford, "Balancing the Force," 20; Donnelly and Kagan, Ground Truth, 123. Modular force consists of a combined arms brigade combat team as the central tactical unit, complemented by five support brigades: battlefield surveillance brigade, fires brigade, combat aviation brigade, maneuver enhancement brigade, and sustainment brigade. These formations are displayed in appendix D. 
On the positive side, the modular brigade concept fits well with conducting operations in a complex environment. By having self-contained and interchangeable brigades, modularity has inherent flexibility to adapt the composition of the land force in response to changes in the environment. Conceptually, the ability to constantly tailor and re-tailor a division with the right mix of BCTs and support brigades also gives the force the expeditionary qualities needed to contend effectively with transitions between rapid combat operations and prolonged stability operations. In addition, the modular brigades feature some organic military police, intelligence collection, signal, combat engineer, human intelligence, civil affairs, psychological, and public affairs assets that were not previously organic to brigades. ${ }^{257}$ These assets are critical as they provide some of the most versatile and effective nonlethal resources to achieve COIN and stability efforts, such as security, justice and rule of law, essential services, and social wellbeing. ${ }^{258}$

However, there are significant disadvantages for COIN operations as the modular brigade concept was designed to accomplish operations across the spectrum of conflict, but optimized for offensive combat operations. ${ }^{259}$ Being designed to respond quickly with smaller, more lethal forces with decisive maneuver enabled by advanced information systems, precision weapons, and joint fires, the BCT was optimized to defeat the direct threats to the US and its partners quickly and decisively, but not to conduct sustained operations to address the underlying cause of those threats. Therefore, the modular force requires a broader range of capabilities: adept at

\footnotetext{
${ }^{257}$ Brian G. Watson, "Reshaping the Expeditionary Army to Win Decisively: The Case for Greater Stabilization Capacity in The Modular Force,” The US Army Professional Writing Collection, written for the Strategic Studies Institute of the US Army War College (August 2005), http://www.army.mil/professionalwriting/volumes/volume3/december_2005/12_05_2.html (accessed February 17, 2009).

${ }^{258}$ US Army FM 3-24, Counterinsurgency, 8-1; US Army FM 3-07, Stability Operations, 2-3, 2-5.

${ }^{259}$ Ford, "Balancing the Force,” 22.
} 
simultaneously destroying an adversary’s military capability, removing the regime, and maintaining the long-term stability needed to foster progress towards a free and open society. ${ }^{260}$

One area for improvement is restoring the number of subordinate maneuver battalions in the heavy and infantry BCTs to three instead of the current two. Adding a third maneuver battalion would restore tactical flexibility and robustness to the brigade. ${ }^{261}$ The Stryker BCT has retained a third battalion in its organization for good reason-to provide more infantry support. The adding of a battalion is critical for operations in a COIN environment, where units must have sufficient "boots on the ground" to secure and control the population, critical capabilities, and resources while conducting full spectrum operations. ${ }^{262}$

Another improvement is to increase the levels of combat support and combat service support units, specifically the number of sustainment and maneuver enhancement brigades (MEB). Although the modular brigades did gain some of these assets as mentioned, the level of these units represents a minimalist approach, barely capable of accomplishing the tasks necessary to support combat operations-let alone the additional tasks required for COIN and stability operations. ${ }^{263}$ As seen in Iraq, the BCTs and support brigades are short of critical "low density” units, such as engineers, civil affairs and military police, and rely heavily on augmentation from the reserve component. Clearly, the three active component MEBs (a fourth is currently being built) are not sufficient to support the requirements of approximately 18 BCTs in Iraq, nor the eventual 48 BCTs within the active component. ${ }^{264}$

\footnotetext{
${ }^{260}$ Watson, "Reshaping the Expeditionary Army to Win Decisively.”

${ }^{261}$ Donnelly and Kagan, Ground Truth, 126.

${ }^{262}$ Feickert, “U.S. Army’s Modular Redesign,” 4; US Army FM 3-07, Stability Operations, 2-2.

${ }^{263}$ Watson, "Reshaping the Expeditionary Army to Win Decisively."

${ }^{264}$ Donnelly and Kagan, Ground Truth, 114, 124-126. This is part of the reason for a continuous level of army reserve component mobilization of 80,000 to 1000,000 in Iraq.
} 
Therefore, the Army must address the imbalance of combat support/service support forces for long-term COIN and stabilization campaigns. ${ }^{265}$ Although the main effort of the modular force design and implementation must remain on improving the combat effectiveness of the BCT in prosecuting decisive operations, more combat support/service support units must be modular and available to "plug into" a division’s headquarters once conditions are set to provide the long-term nonlethal capabilities required in COIN and stability operations. Continued neglect of these supporting units places the BCTs and the overall COIN objective at significant risk. ${ }^{266}$

Despite the disadvantages, in practice the modular BCTs were able to pacify a much more difficult insurgency in Iraq with a lower force density than used in Malaya (Malaya's 20.8 to Iraq's 16.8). This achievement is significant, since the operational environment factors provided earlier would logically indicate that an increased security force ratio would be required in Iraq when compared against the 20:1000 level used to pacify Malaya. The success in Iraq with the low troop density lies partially within the advantages of the modular brigades, the Army's training, and the tactics and strategy used. Even with the thinness in numbers, the US-led COIN force was successful through the synergy of its coordinated and unified civil-military effort, its leaders and soldiers, and the BCT’s technological advancements of increased mobility, surveillance and intelligence collection, improved communication infrastructure and integration of joint capabilities. ${ }^{267}$

Although technology can greatly aid the COIN effort, technology alone is not decisive as it cannot bring physical and psychological security to the population. As the experience in Iraq has made clear, the most important resource is the soldier on the ground, since numbers still matter when the goal is to secure the population. Although the first modular BCTs began

\footnotetext{
${ }^{265}$ Ibid., 124-125.

${ }^{266}$ Watson, "Reshaping the Expeditionary Army to Win Decisively."

${ }^{267}$ US Army FM 3-0, Operations, appendix c; Feickert, “U.S. Army’s Modular Redesign,” 6.
} 
operations in Iraq in 2005 with the $3^{\text {rd }}$ Infantry Division and $101^{\text {st }}$ Air Assault Division, success against the insurgency was not realized until the force levels begun to approach the 20:1000 level in mid 2007. This force level was attained through the Coalition and ISF "surge" and the emergence of the SoI. 


\section{APPENDIX E Modular Brigade Combat Teams}
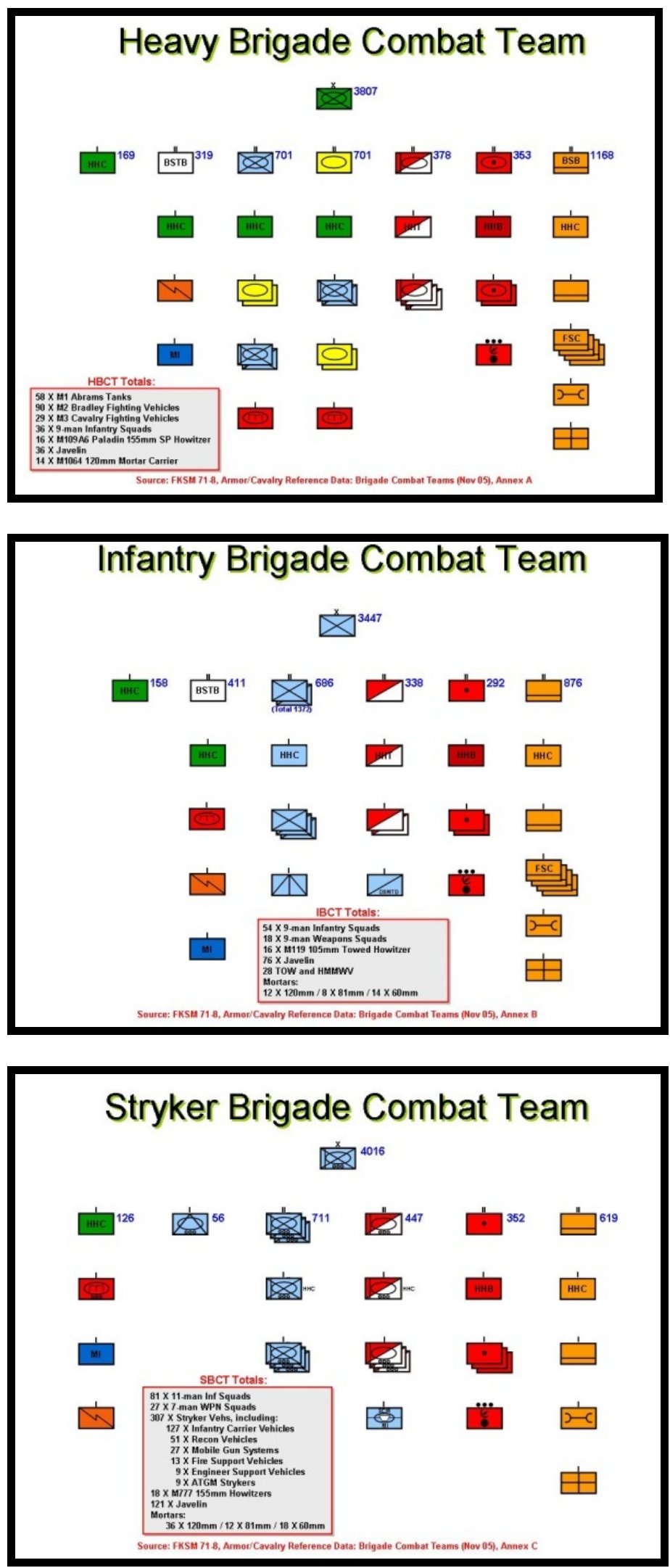


\section{BIBLIOGRAPHY}

\section{Books}

Blij, Harm De. Why Geography Matters: Three Challenges Facing America. New York: Oxford University Press, Inc., 2005.

Birtle, Andrew J. U.S. Army Counterinsurgency and Contingency Operations Doctrine, 18601941. Washington, D.C.: Center of Military History, 1998. . U.S. Army Counterinsurgency and Contingency Operations Doctrine, 1942-1976. Washington, D.C.: Center of Military History, 2006.

Boot, Max. The Savage Wars of Peace: Small Wars and the Rise of American Power. New York: Basic Books, Perseus Books Group, 2002.

Citino, Robert M. Blitzkrieg to Desert Strom: The Evolution of Operational Warfare. Lawrence: University Press of Kansas, 2004.

Donnelly, Thomas, and Frederick W. Kagan. Ground Truth: The Future of U.S. Land Power. Washington D.C.: The AEI Press, 2008.

Galula, David. Counterinsurgency Warfare: Theory and Practice. 1964. Reprint, St. Petersburg, FL: Hailer Publishing, 2005.

Gordon, Michael R., and General Bernard E. Trainor. COBRA II: The Inside Story of the Invasion and Occupation of Iraq. New York: Pantheon Books, 2006.

Huntington, Samuel P. The Clash of Civilizations and the Remaking of World Order. New York: Simon and Schuster, 1996.

O’Neill, Bard E. Insurgency and Terrorism: From Revolution to Apocalypse. $2^{\text {nd }}$ ed. Dulles, VA: Potomac Books, Inc., 2005.

Ricks, Thomas E. Fiasco: The American Military Adventure in Iraq. New York: Penguin Press, 2006.

Salmon, Wesley C. Causality and Explanation. New York: Oxford University Press, Inc., 1998.

Sorley, Lewis. A Better War: The Unexamined Victories and Final Tragedy of America's Last Years In Vietnam. Orlando, FL: Harvest Book Harcourt, Inc., 380.

Thompson, Sir Robert. Defeating Communist Insurgency: The Lesson of Malaya and Vietnam. 1966. Reprint, St. Petersburg, FL: Hailer Publishing, 2005.

Trinquier, Roger. Modern Warfare: A French View of Counterinsurgency. 1961. Reprint, Fort Leavenworth, KS: Combat Studies Institute Press, 1985.

Turabian, Kate L. A Manual for Writers of Research Papers, Theses, and Dissertations. $7^{\text {th }}$ ed. Chicago: University of Chicago Press, 2007. 
Wright, Dr. Donald P., and Colonel Timothy R. Reese. On Point II: Transition to the New Campaign. Fort Leavenworth, KS: Combat Studies Institute Press, 2008.

\section{Military Doctrine Manuals}

NATO AJP 3.4.4 (Draft). Allied Joint Publication for Counterinsurgency (COIN). November 2008.

United States Department of the Army. FM 3-0, Operations. Washington, D.C.: Headquarters United States Army, 2008.

. FM 3-07, Stability Operations. Washington, D.C.: Headquarters United States Army, 2008.

. FM 3-24, Counterinsurgency. Washington, D.C.: Headquarters United States Army, 2006.

FM 5-0, Army Planning and Orders Production. Washington, D.C.: Headquarters United States Army, 2005.

FM 7-98, Operations in a Low-Intensity Conflict. Washington, D.C.: Headquarters, Department of the Army, 1992.

. FM 34-130, Intelligence Preparation of the Battlefield. Washington, D.C.: Headquarters United States Army, 1994.

. FM 90-8, Counterguerrilla Operations. Washington, D.C.: Headquarters, Department of the Army, 1986.

United States Joint Forces Command. Joint Publication 3-0, Joint Operations. Suffolk, VA: United States Joint Doctrine Group, 2006 with change 1, 2008.

. Joint Publication 5-0, Joint Operation Planning. Suffolk, VA: United States Joint Doctrine Group, 2006.

United States Marine Corps. Small Wars Manual, United States Marine Corps, 1940.Manhattan, KS: Sunflower University Press 1991.

\section{$\underline{\text { Journals }}$}

Alford, Julian D., and Scott A. Cuomo. "Operational Design for ISAF in Afghanistan: A Primer.” Joint Forces Quarterly 53 (2 ${ }^{\text {nd }}$ Quarter 2009): 92-98.

Birtle, Andrew J. "PROVN, Westmoreland, and the Historians: A Reappraisal.” Journal of Military History 72 (October 2008): 1212-1247.

Malkansian, Carter. "Did the Coalition Need More Forces in Iraq? Evidence from Al Anbar." Joint Force Quarterly, no. 46 (July 2007): 120-126.

Mattis, James M. “USJFCOM Commander’s Guidance for Effects-based Operations.” Parameters 38, no. 3, US Army War College Quarterly (Autumn 2008). 
McFate, Montgomery. "Anthropology and Counterinsurgency: The Strange Story of the Curious Relationship.” Military Review (March-April 2005): 24-38.

Quinlivan, James T. "Burden of Victory: The Painful Arithmetic of Stability Operations.” RAND Review 27, no. 2 (Summer 2003). http://www.rand.org/pubs/corporate_pubs/CP22-200308/ (accessed September 29, 2008).

"Force Requirements in Stability Operations.” Parameters, US Army War College Quarterly (Winter 1995). http://www.carlisle.army.mil/usawc/parameters/1995/quinliv.htm (accessed September 29, 2008).

Russell, James. "Strategic Implications of the Iraq Insurgency.” Middle East Review of International Affairs 8, no. 2 (June 2004). http://www.ccc.nps.navy.mil/people/biolinks/russell/russell\%20-\%20insurgency.pdf (accessed January 13, 2009).

\section{Public Documents, Pamphlets and Reports}

Ahmed, Farook. "Sons of Iraq and Awakening Forces.” Institute for the Study of Wars, Backgrounder no. 23 (February 21, 2008).

http://www.understandingwar.org/files/reports/Backgrounder\%2023\%20Sons\%20of\%20I raq\%20and\%20Awakening\%20Forces.pdf (accessed January 13, 2009).

Bosnia’s State Health Protection Office. "Bosnia-Herzegovina's War Casualties Estimation.” (March 29, 1996). http://www.hdmagazine.com/bosnia/census.html (accessed October 1, 2008).

Bush, George W. "President's Address to the Nation: New Way Forward in Iraq.” White House database online (January 10, 2007). http://www.whitehouse.gov/news/releases/2007/01/20070110-7.html (accessed September 27, 2008).

Campbell, Jason H., and Jeremy Shapiro. “Afghanistan Index: Tracking Variables of Reconstruction and Security in Post-9/11 Afghanistan.” January 2009 (Washington D.C.: The Brookings Institute, 2009). http://www.brookings.edu/foreign-policy/afghanistanindex.aspx (accessed March 10, 2009).

Christoff, Joseph A. "Rebuilding Iraq: Preliminary Observations on Challenges in Transferring Security Responsibilities to Iraqi Military and Police.” United States Government Accountability Office Testimony (March 14, 2005). http://www.gao.gov/new.items/d05431t.pdf (accessed January 26, 2009).

CIA World Fact Book. "Population Rank Order.” https://www.cia.gov/library/publications/theworld-factbook/rankorder/2119rank.html (accessed 1 October 1, 2008).

“DESERT CROSSING.” The National Security Archive no. 207 (July 22, 1999). http://www.gwu.edu/ nsarchiv/NSAEBB/NSAEBB207/index.htm (accessed October 12, 2008). 
Feickert, Andrew. “U.S. Army’s Modular Redesign: Issues for Congress.” Congressional Research Service Report for Congress (May 5, 2006). http://fpc.state.gov/documents/organization/67816.pdf (accessed January 29, 2009).

Ford, Honorable Nelson. "Balancing the Force: Considerations of Size, Structure, and Risk.” Moderated by Dr. Peter Singer, the Brookings Institute transcript (October 22, 2008). http://www.brookings.edu/events/2008/1022_military.aspx (accessed January 29, 2008).

International Council on Security and Development (ICOS) maps. http://www.icosmaps.net/ (accessed March 14, 2009).

Jones, Seth G. "Counterinsurgency in Afghanistan.” RAND study prepared for the Office of the Secretary of Defense (Santa Monica, CA: RAND Corporation, 2008).

Jones, Seth G., Jeremy M. Wilson, Andrew Rathmell, and K. Jack Riley. "Establishing Law and Order After Conflict.” RAND Corporation monograph series (Santa Monica, CA: RAND Corporation, 2005). http://www.rand.org/pubs/monographs/2005/RAND_MG374.pdf (accessed September 19, 2008).

Katzman, Kenneth. “Afghanistan: Post Taliban Governance, Security, and U.S. Policy.” Congressional Research Service Report for Congress, Order Code RL30588 (February 9, 2009). http://www.fas.org/sgp/crs/row/RL30588.pdf (accessed March 12, 2009).

Komer, R. W. "The Malayan Emergency in Retrospect: Organization of a Successful Counterinsurgency Effort.” Prepared for the Advanced Research Projects Agency, R-957 (Santa Monica, CA: RAND Corporation, February 1972). http://www.rand.org/pubs/reports/2005/R957.pdf (accessed January 2, 2009).

McGrath, John J. "Boots on the Ground: Troop Density in Contingency Operations.” Global War on Terrorism Occasional Paper 16 (Fort Leavenworth, KS: Combat Studies Institute Press, 2006).

. "The Other End of the Spear: The Tooth-to-Tail Ratio (T3R) in Modern Military Operations.” The Long War Series Occasional Paper 23 (Fort Leavenworth, KS: Combat Studies Institute Press, 2007).

National Geographic. "Understanding Afghanistan: Land in Crisis.” http://www.nationalgeographic.com/landincrisis/ethnic.html (accessed March 14, 2009).

O’Hanlon, Michael E. "Iraqi Index: Tracking Variables of Reconstruction and Security in PostSaddam Iraq.” April 2006 (Washington D.C.: The Brookings Institute, 2008). http://www.brookings.edu/saban/iraq-index.aspx (accessed October 13, 2008).

. "Iraqi Index: Tracking Variables of Reconstruction and Security in Post-Saddam Iraq." January 2008 (Washington D.C.: The Brookings Institute, 2008). http://www.brookings.edu/saban/iraq-index.aspx (accessed October 13, 2008).

"POLO STEP.” The National Security Archive no. 214 (August 15, 2002). http://www.gwu.edu/ nsarchiv/NSAEBB/NSAEBB214/index.htm (accessed October 12, 2008). 
School of Advanced Military Studies. “Art of Design: Student Text Version 1.0.” (September 24, 2008). Prepared by Booz Allen Hamilton for US Army Training and Doctrine Command.

United Nations Children's Fund (UNICEF). Afghanistan Demographics Statistics. http://www.unicef.org/infobycountry/afghanistan_statistics.html\#48 (accessed March 17, 2009).

United Nations-Habitat. “Urbanization: Mega and Meta Cities, New City State?” State of the Worlds Cities, 2006/7.

http://ww2.unhabitat.org/mediacentre/documents/sowcr2006/SOWCR\%202.pdf (accessed 9 March 2009).

United States Bureau of the Census. "Table 8: Annual Estimates of the Population of the United States.” (July 2004). http://www.census.gov/popest/states/NST-ann-est2004.html (accessed October 2, 2008).

United States Bureau of Justice Statistics. "Law Enforcement Statistics.” (2004). http://www.ojp.usdoj.gov/bjs/lawenf.htm (accessed October 2, 2008).

United States Department of Defense. "Measuring Stability and Security in Iraq.” Quarterly Reports. Report to Congress in accordance with the Department of Defense Appropriations Act of 2006-2008. http://www.defenselink.mil/home/features/Iraq_Reports/ (accessed January 13, 2009).

"Progress Toward Security and Stability in Afghanistan.” January 2009. Report to Congress in accordance with the 2008 National Defense Authorization Act (Section 1230, Public Law 110-181). http://www.defenselink.mil/pubs/OCTOBER_1230_FINAL.pdf (accessed March 10, 2009).

United States Department of State. July 2007 Iraq population estimate, under Background Notes/Iraq. http://www.state.gov/r/pa/ei/bgn/6804.htm (accessed February 15, 2009).

United States Joint Forces Command. “The Joint Operating Environment 2008: Challenges and Implications for the Future Joint Force.” Center for Joint Futures (J59) (November 25, 2008). https://us.jfcom.mil/sites/J5/j59/default.aspx (accessed March 6, 2009).

Watson, Brian G. "Reshaping the Expeditionary Army to Win Decisively: The Case for Greater Stabilization Capacity in The Modular Force.” The US Army Professional Writing Collection, written for the Strategic Studies Institute of the US Army War College (August 2005). http://www.army.mil/professionalwriting/volumes/volume3/december_2005/12_05_2.ht ml (accessed February 17, 2009).

\section{Periodicals}

Abramowitz, Michael, and Robin Write. "Bush to Add 21,500 Troops in an Effort to Stabilize Iraq.” Washingtonpost.com, January 11, 2007. http://www.washingtonpost.com/wpdyn/content/article/2007/01/10/AR2007011002437.html (accessed October 2, 2008). 
Bajoria, Jayshree. “al-Qaeda.” Council on Foreign Relations, April 18, 2008. http://www.cfr.org/publication/9126/ (accessed 14 March 2009).

Bene, Steve. “Not Enough Troops in Iraq?” Washington Monthly, January 9, 2005. http://www.washingtonmonthly.com/archives/individual/2005_01/005422.php (accessed September 27, 2008).

Bowman, Michael. "US Legislators Debate Resolution Opposing Troop Surge in Iraq.” (January 21, 2007). http://www.globalsecurity.org/wmd/library/news/iraq/2007/01/iraq-070121voa01.htm (accessed September 29, 2008).

Brown, John S. “Numerical Considerations in Military Occupations.” Army, April 2006. http://findarticles.com/p/articles/mi_qa3723/is_200604/ai_n17175276/pg_1 (accessed December 20, 2008).

Bruno, Greg. “U.S. Security Agreements and Iraq.” Council on Foreign Relations, November 18, 2008. http://www.washingtonpost.com/wpdyn/content/article/2008/11/18/AR2008111801118.html (accessed December 20, 2008).

Budiansky, Stephen. “Formula for How Many Troops We Need.” Washington Post, May 10, 2004. http://www.spokesmanreview.com/breaking/story.asp?ID=2149 (accessed September 29, 2008).

Bumiller, Elisabeth. “General Sees Long Term for Afghanistan Buildup.” New York Times, February 18, 2009. http://www.nytimes.com/2009/02/19/washington/19pentagon.html?ref=world (accessed March 12, 2009).

Dubik, Lieutenant General James M. Ret. “No Holy Grails, No Silver Bullets.” Army, February 2009, 18-20.

Dwyer, Jim. “A Nation at War: In the Field-V Corps Commander; A Gulf Commander Sees a Longer Road.” New York Times, March 28, 2003. http://query.nytimes.com/gst/fullpage.html?res=9C01E4D81F30F93BA15750C0A9659C 8B63\&sec=\&spon=\&pagewanted=2 (accessed February 13, 2009).

Gordon, Michael R., and Mark Mazzetti. “General Warns of Risks if Iraq if G.I.’s are Cut.” New York Times, November 16, 2006. http://www.nytimes.com/2006/11/16/world/middleeast/16policy.html?_r=2 (accessed September 27, 2008).

“Iraq Blast Damages Shia Shrine.” BBC News Middle East, February 22, 2006. http://news.bbc.co.uk/2/hi/middle_east/4738472.stm (accessed January 21, 2009).

Joyner, James. “John Murtha Calls for Iraq Pullout.” Outside the Beltway.com (November 17, 2005). http://www.outsidethebeltway.com/archives/john_murtha_calls_for_iraq_pullout/ (accessed October 2, 2008).

Kagan, Robert, and William Kristol. “Too Few Troops.” Weekly Standard 9, no. 31, April 26, 2004. 
http://www.weeklystandard.com/Content/Public/Articles/000/000/003/977ovnnr.asp?pg= 2 (accessed February 16, 2009).

Kami, Aseel. “Iraq Takes over Guard Programme in Restive Province.” Reuters, January 4, 2009. http://www.reuters.com/article/latestCrisis/idUSL4641298 (accessed on January 13, 2009).

Kiel, Kathy, and Bill Nichols. "Democrats Reject Bush's 'Way Forward'.” USA Today, January 11, 2007. http://www.usatoday.com/news/washington/2007-01-10-dems-bush-iraq_x.htm (accessed October 2, 2008).

Leverett, Flynt. “A ‘Formula’ for Lifting America’s Standing in the Middle East.” Council on Foreign Relations, October 12 2007. Interviewed by Bernard Gwertzman. http://www.cfr.org/publication/14471/leverett.html (accessed September 29, 2008).

McMichael, William. “IG: Dead Count Toward Iraqi Force Strength.” ArmyTimes, April 28, 2008. http://www.armytimes.com/news/2008/04/military_isfreport_042508/ (accessed January 21, 2009).

Phillips, James. “President Bush’s New Way Forward in Iraq.” WebMemo no. 1304 published by The Heritage Foundation (January 11, 2007). http://www.heritage.org/research/MiddleEast/wm1304.cfm (accessed October 2, 2008).

Stewart, Phil. “Iraq Violence at 5-1/2 Year Low Petraeus Says.” Reuters, December 9, 2008. http://www.newsdaily.com/stories/tre4b86g7-us-iraq-petraeus/ (accessed December 20, 2008).

United States Department of Defense. "Officials in Iraq Note Approaching al-Askari Mosque Bombing Anniversary.” Armed Forces Press Service (February13, 2007). http://www.defenselink.mil/news/newsarticle.aspx?id=3044 (accessed January 21, 2009).

Warner, Margaret. "Securing Iraq.” Online News Hour, August 22, 2003. A NewsHour with Jim Lehrer Transcript. http://www.pbs.org/newshour/bb/middle_east/july-dec03/iraq_822.html (accessed September 27, 2008).

Willis II, Thomas E. "Lessons from the Past: Successful British Counterinsurgency Operations in Malaya 1948-1960.” Infantry Magazine, July-August 2005. http://findarticles.com/p/articles/mi_m0IAV/is_4_94/ai_n16084290 (accessed October 2, 2008). 